\title{
Trace metal composition of rainwater and aerosol from Kolkata, a megacity in eastern India
}

\author{
Aditi Majumdar ${ }^{1} \cdot$ Jaydeep Satpathy $^{1} \cdot$ Jariya Kayee $^{2} \cdot$ Reshmi Das $^{1,3}$ (I)
}

Received: 21 August 2020 / Accepted: 20 November 2020 / Published online: 1 December 2020

(c) Springer Nature Switzerland AG 2020

\begin{abstract}
India is one of the world's wettest countries receiving over $1000 \mathrm{~mm}$ of rainfall annually and also one of the countries experiencing regular floods and droughts. This study quantifies elemental composition of rainwater and aerosol collected simultaneously during 2019 monsoon season from Kolkata, a megacity in Eastern India marred by air pollution to understand sources and estimate wet deposition flux. Elemental composition ( $\mathrm{Na}, \mathrm{Ca}, \mathrm{Mg}, \mathrm{Al}, \mathrm{Fe}, \mathrm{Mn}, \mathrm{V}, \mathrm{Cr}, \mathrm{Ni}, \mathrm{Cu}, \mathrm{Zn}, \mathrm{Cd}$, $\mathrm{Pb})$ of rainwater was measured in ICP MS along with $\mathrm{pH}$, conductivity, chloride $\left(\mathrm{Cl}^{-}\right)$, nitrate $\left(\mathrm{NO}_{3}{ }^{-}\right)$and sulphate $\left(\mathrm{SO}_{4}{ }^{2-}\right)$ ions. Trace metal composition of $\mathrm{PM}_{10}$ collected in between rain events were also analysed to understand anthropogenic sources and atmospheric leaching of metals. Crustal enrichment factors (EFs) identified anthropogenic sources for $\mathrm{Ni}, \mathrm{Cu}$, $\mathrm{Zn}, \mathrm{Pb}$ and $\mathrm{Cd}$ in $\mathrm{PM}_{10}$. Principal component analysis (PCA) identified three anthropogenic sources, industrial emission, traffic emission and waste incineration in addition to the natural background from the crustal dust for the aerosol metals. Majority of rainwater samples had almost neutral pH (average $6.81 \pm 0.74,1 \mathrm{SD}$ ), with a range of 5.4 to 8.0. In rainwater, $\mathrm{Na}$ and $\mathrm{Cl}^{-}$had marine origin and majority of $\mathrm{SO}_{4}{ }^{2-}$ had non-marine sources. $\mathrm{Cu}, \mathrm{Zn}, \mathrm{Cd}, \mathrm{V}, \mathrm{Cr}$ and $\mathrm{Pb}$ concentrations of rainwater follow the trend in $\mathrm{PM}_{10}$ most likely because part of the metals are derived from aerosol leaching. The EFs indicated that all the metals except Fe had anthropogenic origin in rainwater. The wet deposition fluxes were in the order of $\mathrm{Ca}>$ $\mathrm{Na}>\mathrm{Mg}>\mathrm{Al}>\mathrm{Zn}>\mathrm{Fe}>\mathrm{Mn}>\mathrm{Cu}>\mathrm{Ni}>\mathrm{Pb}>\mathrm{Cr}>\mathrm{V}>\mathrm{Cd}$. Overall, the results show significant influence of anthropogenic sources on rainwater chemistry in addition to natural soil dust and marine aerosols. In spite of anthropogenic influence, the trace metal and anion concentrations in rainwater are well within the limits prescribed by World Health Organization (WHO), European Union (EU), USA and Indian Drinking Water Standards.
\end{abstract}

Keywords Rainwater $\cdot$ Trace element $\cdot \mathrm{PM}_{10} \cdot$ Enrichment factor $\cdot$ Principal component analysis $\cdot$ Wet deposition flux

\section{Introduction}

Anthropogenic activities are constantly altering the natural chemical composition of the atmosphere. Air pollutants are mainly produced from combustion of fossil fuels, smelting and roasting of ores for metal refining, endless urban constructions and waste incineration [84, 111, 126].
Atmospheric pollutants often have long-range transport pathways that have an important contribution on regional climate and pollution levels, since air masses passing through industrially developed regions are heavily loaded with anthropogenic pollutants $[60,115]$.

Atmospheric wet and dry depositions are the major processes that remove contaminants from the atmosphere [6].

\section{Electronic supplementary material The online version of this article (https://doi.org/10.1007/s42452-020-03933-2) contains supplementary material, which is available to authorised users.}

\footnotetext{
$\triangle$ Reshmi Das, reshmidas.sest@jadavpuruniversity.in | ${ }^{1}$ School of Environmental Studies, Jadavpur University, Kolkata, India. ${ }^{2}$ Department of Marine Science, Faculty of Science, Chulalongkorn University, Bangkok, Thailand. ${ }^{3}$ Earth Observatory of Singapore, Nanyang Technological University, Nanyang, Singapore.
} 
The continuous process of dry deposition is predominant in areas of low precipitation [86]. In contrast, episodic wet deposition is the most effective process of atmospheric cleansing $[41,129]$. The cleansing of the atmosphere by wet and dry depositions ultimately results in the transfer of both nutrients and contaminants from atmosphere into soil and aquatic ecosystem $[32,48]$. The study of metals in rainwater has gained interest due to increasing air pollution and concern about the adverse environmental and human health effects of the deposited pollutant, particularly metals that become potentially toxic after entering the terrestrial and aquatic environments [95].

Chemical composition of rain water is affected by the local and regional characteristics of air pollutants [96]. Rainwater $\mathrm{pH}$ is controlled by the ionic composition such as $\mathrm{Na}^{+}, \mathrm{K}^{+}, \mathrm{Mg}^{2+}, \mathrm{Ca}^{2+}, \mathrm{Cl}^{-}, \mathrm{HCO}^{3-}, \mathrm{SO}_{4}{ }^{2-}, \mathrm{NO}_{3}{ }^{-}$and $\mathrm{NH}_{4}{ }^{+}$ $[66,90,106]$. For example, presence of atmospheric gasses such as $\mathrm{SO}_{2}$ and $\mathrm{NO}_{x}$ which are precursors of major acids $\mathrm{H}_{2} \mathrm{SO}_{4}$ and $\mathrm{HNO}_{3}$, respectively, results in acidic precipitation $[7,24,74]$. In contrast, $\mathrm{CaCO}_{3}$ in airborne dust and/ or presence of ammonia released from anthropogenic or natural sources can neutralize acidity in rainwater $[36,98]$. Thus, substances of anthropogenic origin (industry, agriculture and fertilizers, combustion of fossil fuels) such as $\mathrm{SO}_{2}, \mathrm{NO}_{x}$, ammonia, and toxic metals, and those of natural origin (sea salt and terrestrial aerosols) such as $\mathrm{Na}^{+}, \mathrm{Mg}^{2+}$, $\mathrm{Ca}^{2+}, \mathrm{Cl}^{-}[14]$ are present in atmospheric precipitation.

Globally, studies pertaining to geochemistry of rainwater have gained tremendous momentum primarily due to two reasons $[9,29,64,73,124]$. First, due to the toxicity of certain metals (such as $\mathrm{Pb}, \mathrm{Cd}, \mathrm{Cr}, \mathrm{As}, \mathrm{Hg}$ ), their capability to bioaccumulate and biomagnify and carcinogenic properties, high concentrations of such metals in precipitation are perilous for both terrestrial and aquatic ecosystems $[62,92,122]$. Hence understanding the chemical composition of rainwater, particularly the pollutants are important for the environment and ecosystem. Second, water shortage has become a pressing issue nowadays, and rainwater harvesting (RWH) is considered a viable water supply for urban regions $[12,38]$. In many regions, $\mathrm{RWH}$ is the only sustainable way to obtain drinking water and used for crop irrigation and the recharging of aquifers [51, 77]. Thus, chemical characterization of rainwater is required to determine the treatment necessities.

There have been numerous studies on the major ion composition of rainwater in India [17, 39, 53, 67, 97, 109, $114,119]$ to understand the undergoing processes such as $\mathrm{pH}$ control, "in cloud" and below-cloud scavenging and understanding natural verses anthropogenic sources ( [61, $66,81,89]$. However, none of the studies quantified trace metal concentrations simultaneously in rainwater and aerosol and measure their wet deposition fluxes. Additionally, in India, compliance with the rainwater harvesting has become a necessary requirement for major construction projects to be fulfilled when receiving environmental clearance $[31,67]$. Hence, knowledge about the chemistry of the rainwater that is harvested is of utmost importance. To fill in the knowledge gaps, this pilot study investigates trace metal concentrations in aerosol and rainwater during monsoon season in an Indian megacity, Kolkata. Previous studies investigated trace metals in atmospheric particulate matter $\left(\mathrm{PM}_{10}\right.$ and $\left.\mathrm{PM}_{2.5}\right)$ from Kolkata $[25,57]$; however, these studies did not quantify rainwater metal concentrations from the megacity. The main objectives of this study are to understand aerosol leaching, quantify trace metal in rainwater and understand the sources of trace metals and quantify the atmospheric wet deposition (AWD) fluxes.

\section{Methods}

\subsection{Sampling}

Aerosol and rainwater sampling was carried out in Kolkata [22 $22^{\prime} 57.53^{\prime \prime} \mathrm{N}, 88^{\circ} 22^{\prime} 18.66^{\prime \prime} \mathrm{E}$.], the capital of the state of West Bengal and the only megacity in eastern India. The major industries around the city are jute mills, paper and pulp industries, tanneries, textile mill, thermal power plants and oil refineries. The city experiences a tropical wet-and-dry climate [25]. Generally, monsoon commences in June and lasts till September. In 2019, monsoon was delayed by a month and commenced in July, lasted till October and supplied the city with most of its annual rainfall (Fig. 1). $72 \mathrm{~h}$ of air mass back trajectories at $500 \mathrm{~m}$ above ground level (a.g.l) terminating at Kolkata during the sampling period showed that majority of the air mass originated over Arabian Sea and blew over the Indian landmass before reaching the city (Fig. 1).

Rainwater and aerosol were collected on the roof top of School of Environmental Studies building, Jadavpur University, approximately $24 \mathrm{~m}$ a.g.l. The building has no wet laboratories; hence, there are no ventilation exhausts on the rooftop to contribute blanks from acid fumes. The rainwater samples were collected in $500 \mathrm{ml}$ high density polyethylene (HDPE) bottles through HDPE funnel covered with nylon net. The bottles, funnels and the net were pre cleaned with $2 \%$ reagent grade $\mathrm{HNO}_{3}$ and thoroughly washed several times with ultrapure water followed by overnight drying at $60{ }^{\circ} \mathrm{C}$ in a convection oven. The bottles were placed on the rooftop several minutes after commencement of rain and immediately removed either after rain stopped or the bottle filled up, which ever was earlier to avoid any dust or dry deposition. A total of thirteen rain water samples and two blanks were collected between July and October 

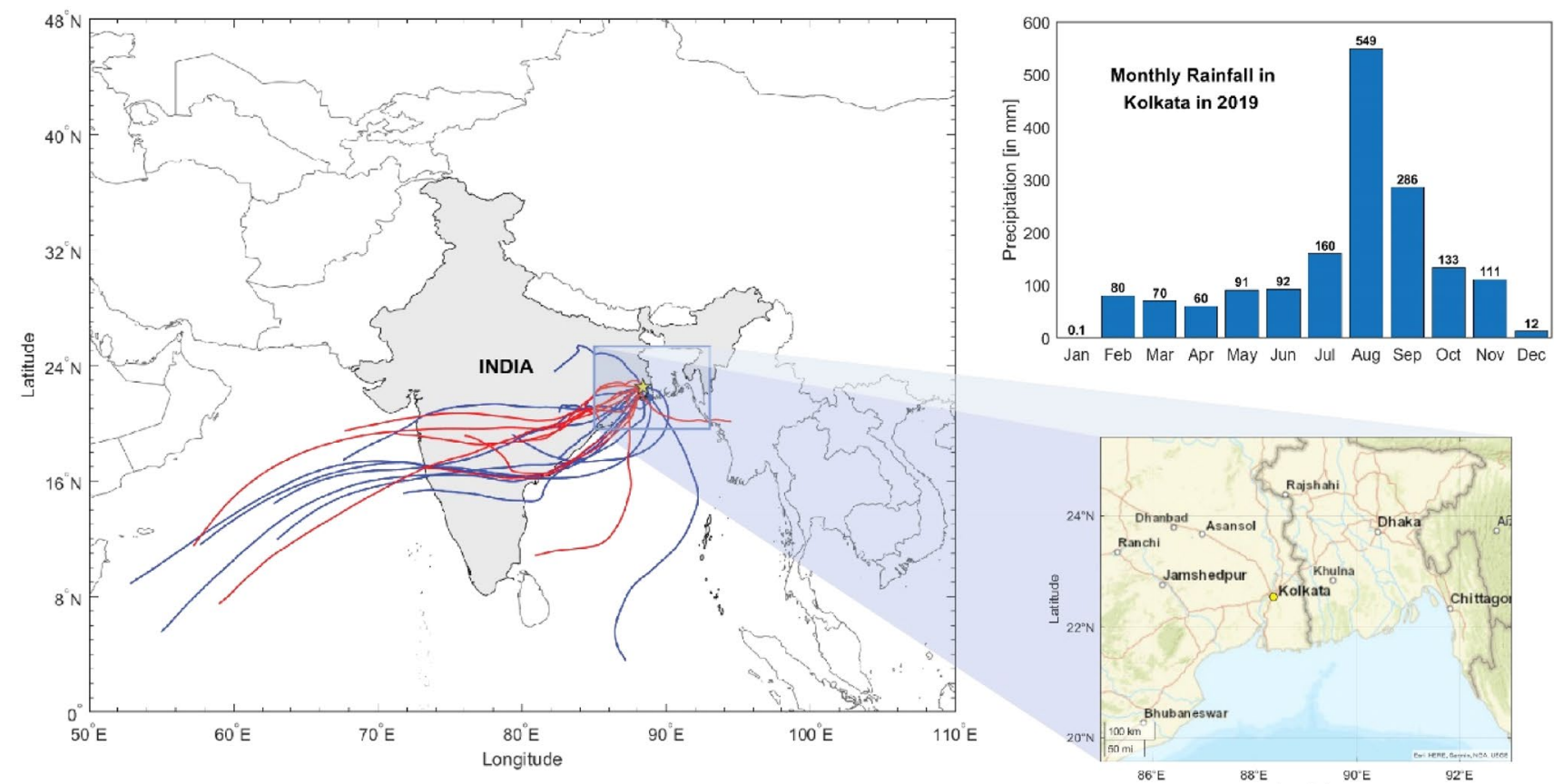

Fig. 1 Backward air mass trajectories terminating at Kolkata backtraced for $72 \mathrm{~h}$ at $500 \mathrm{~m}$ above mean sea-level using the HYSPLIT model during the sampling days. Red trajectories are for days when aerosol $\left(\mathrm{PM}_{10}\right)$ was collected and blue trajectories are for rainwater collection days. The inset bar diagram shows monthly distribution of rainfall over Kolkata in 2019
2019. For the procedural blanks, the bottles with the funnels covered by net were taken to the rooftop and ultrapure water was poured inside the bottles. The blanks samples were treated similar to the rainwater samples.

A total of ten $\mathrm{PM}_{10}$ samples were collected in between rain events using a deployable particulate sampler (DPS) pump from Leland Legacy operating at $10 \mathrm{~L} / \mathrm{min}$. 24-h samples (usually starting at $8 \mathrm{AM}$ ) were collected on prewashed 47-mm PTFE (polytetrafluoroethylene) filters. The PTFE filters were prewashed in acid and blanks collected as described in [26] to minimize filter blanks. The filters were weighed and sealed immediately in a petri dish and stored inside a desiccator after the collection. Concentrations of $\mathrm{PM}_{10}$ were assessed gravimetrically.

\subsection{Chemical analysis}

Trace metal analysis of rainwater and aerosol samples was carried out at the Earth Observatory of Singapore, Nanyang Technological University (NTU), Singapore, in a Class 100 metal-free clean chemistry laboratory. Anions were analysed at the Central Environmental Science and Engineering Laboratory at NTU.

\subsubsection{Rainwater}

Immediately after sampling approximately $10 \mathrm{ml}$ of rainwater was filtered through prewashed $0.45 \mu \mathrm{m}$ Acrodisc ${ }^{\oplus}$ Syringe Filters with PTFE membrane into 15-ml HDPE bottles. The filtrates were acidified with several drops of $14 \mathrm{~N}$ ultrapure $\mathrm{HNO}_{3}$ to prevent absorption of trace metals on the bottle wall and preserved for trace element analysis. In the remaining water, $\mathrm{pH}$ and electrical conductivity (referred to as conductivity herein) were immediately measured and the remaining preserved for ion chromatography analysis for anions. $\mathrm{pH}$ was determined using Eutech pH 700 from Thermo Scientific and cross-checked using Toshcon digital $\mathrm{pH}$ meter. Both the $\mathrm{pH}$ meters were calibrated with NIST buffer sets with $\mathrm{pH} 4.01$ and $\mathrm{pH} 6.86$ and the electrode cleaned with distilled water before measuring the unknown samples. The difference in reading between the two instruments was within 0.09 of each other, and the average value was taken. The conductivity of the rainwater samples was measured by using a Systronics conductivity meter. Standard $\mathrm{KCl}$ solutions $(0.01 \mathrm{M}$, $0.001 \mathrm{M}$ concentrations) were used for calibrating the instrument. The conductivity and the temperature probes were rinsed thoroughly with distilled water before calibration. The different standard $\mathrm{KCl}$ solutions were used for calibrating the instrument before measuring the unknown 
rainwater sample. Temperature of the instrument was adjusted as closely as possible to $30 \pm 2{ }^{\circ} \mathrm{C}$.

The rainwater and blank samples were analysed for anions $\left(\mathrm{Cl}^{-}, \mathrm{SO}_{4}{ }^{2-}, \mathrm{NO}_{3}{ }^{-}\right)$using ion chromatography (Dionex ICS-1000 Ion Chromatography System (ICS-1000)). Before running the samples, the ion chromatography system was calibrated using a standard solution (Dionex Seven Anion Standard from Thermo Scientific). All samples were filtered through $0.45-\mu \mathrm{m}$ cellulose acetate syringe filters before being injected into the IC column. By comparing the data obtained from a sample to that obtained from the known standard, sample ions were quantified. The final concentrations were blank-corrected using the average procedural blank concentrations. Averages of the procedural blank were $1.3 \%$ (for $\mathrm{SO}_{4}{ }^{2-}$ ), $1.9 \%$ (for $\mathrm{NO}_{3}{ }^{-}$) and $2 \%\left(\right.$ for $\mathrm{Cl}^{-}$) of the average signal intensity of the samples.

\subsubsection{Particulate matter $\left(\mathrm{PM}_{10}\right)$}

For determination of trace metal concentration, filters were cut into small pieces using a ceramic scissor and placed inside pre-cleaned PTFE vials. The scissor was first washed with ultrapure water followed by methanol before cutting the next sample to prevent any contamination. Trace metals were extracted in 50\% (v/v) 3:1 $\mathrm{HNO}_{3}$ : $\mathrm{HF}$ mixture. The vials were first placed in an ultrasonic bath at $60^{\circ} \mathrm{C}$ for an hour. Then the vials were placed on the hot plate at $150^{\circ} \mathrm{C}$ for $12 \mathrm{~h}$. After cooling down the vials, caps were opened and the filter papers were washed with ultrapure water inside the vials and discarded. The digested samples were then evaporated to dryness and re-dissolved in $5 \mathrm{ml}$ of $50 \% \mathrm{HNO}_{3}$ and dried again. The evaporation and re-dissolving procedure were then repeated a couple of times to ensure complete evaporation of HF. Finally, the dried metal extract was dissolved in $5 \mathrm{ml}$ of $2 \% \mathrm{HNO}_{3}$ and transferred to precleaned vials for ICPMS analysis. Procedural blank was measured on two filters that were taken to the field and brought back and were treated in the same way as the samples. SRM 2783 of Urban Particulate Matter standard was used to test the extraction efficiency and validate the method [25].

\subsection{ICP MS measurements}

Trace metals ( $\mathrm{Na}, \mathrm{Ca}, \mathrm{Mg}, \mathrm{Al}, \mathrm{Fe}, \mathrm{Mn}, \mathrm{V}, \mathrm{Cr}, \mathrm{Ni}, \mathrm{Cu}, \mathrm{Zn}, \mathrm{Cd}$, $\mathrm{Pb}$ ) were determined in the acidified rainwater samples and aerosol extracts using ICPMS (Inductively Coupled Plasma Mass Spectrometry, Thermo Element 2, USA). High-purity multi-element standard solution (IV-ICPMS$71 \mathrm{~A}$ from Inorganic Ventures) diluted to appropriate concentrations depending on the signal range was used to measure the metal concentrations. One ppb of indium (In) was used as an internal standard to correct for instrument drift. Samples were measured using sample standard bracketing technique. The procedural blank intensities that ranged from 1 to $3 \%$ of the average signal intensity of the samples were subtracted from the sample signal intensities. SRM 2783 of Urban Particulate Matter samples were used for method validation. Recoveries for all metals were found to be $>90 \%$ [25]. The limit of detections (LODs) of all analysed elements was calculated based on three times of the standard deviation (SD) of blank. The value of $L O D$ ranged from $0.0023(\mathrm{~Pb})$ to $2.2717(\mathrm{Ca}) \mathrm{ppb}$ $(n=12)$ (Kayee et. al., 2020). Chemical composition of all the samples (rainwater and aerosol) is given in Table S1 in the supplementary information section. Further details of the analytical procedures are documented in $[25,26]$ and [59].

\subsection{Chemical data analysis}

The measured metal and anion data were further used to calculate the enrichment factor (EF), sea salt component, and wet deposition flux (WDF) and statistical analysis.

\subsubsection{Statistical analysis of the data}

Pearson's correlation coefficient $(r)$ is used to measure the strength of the association between the two variables. The correlation coefficient is considered to be statistically significant if the $p$ values were $\leq 0.05$.

To identify the probable sources of the trace elements in aerosol, principal component analysis (PCA) with varimax rotation and Kaiser normalization is used. In PCA, a multivariate data table is represented as smaller set of variates that have similar patterns in the real world such as source, atmospheric dispersion pathways, etc. Factors with eigenvalues $\geq 1$ are only considered. Eigenvalues $<1$ are negligible from a variance point of view. To select the significant features for the interpretation of each component, factors loadings greater than 0.5 are considered.

All statistical analyses were performed using SPSS for Windows V. 16.0.1.

\subsubsection{Crustal enrichment factor (EF)}

Crustal enrichment factor (EF) is often used to identify anthropogenic sources of metals over natural background. Metal ratios are generally compared with the average upper continental crustal (UCC) composition. In this study, we use UCC composition from Rudnick and Gao [93]. The $\mathrm{EF}$ of an element in a PM and rainwater sample is defined

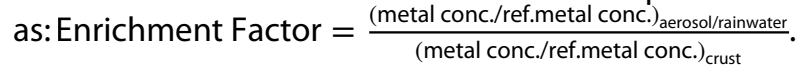

Elements that generally have typically crustal origin such as $\mathrm{Fe}, \mathrm{Al}$ and $\mathrm{Ti}$ are chosen as reference metal. Ti was not 
measured in this study and Fe behaves differently in oxic and anoxic environment, [8]. Hence, we choose a conservative element with high crustal abundance such as $\mathrm{Al}$, as the reference metal in this study $[25,26]$.

\subsubsection{Marine and non-marine sources and marine enrichment factor}

Ionic composition of rainwater helps to understand the relative contribution of marine and non-marine sources. Generally, $\mathrm{Na}$ is taken as reference element with the assumption that all $\mathrm{Na}$ is of marine origin. The equation for the non-sea salt contribution can be written as $[N S S-X]_{l}=\left[X_{i}\right]-[N a+]_{i}\left[\frac{[X]}{[N a+]}\right]_{\text {sea salt }}$

$[N S S-X]_{i}$ is the concentration of non-sea salt concentration of species $X$ in sample $i,\left[X_{i}\right]$ is the total measured concentration of chemical species $X$ in sample $i,\left[\mathrm{Na}^{+}\right]_{i}$ is the concentration of $\mathrm{Na}^{+}$in sample $i$, and $\left\{[X] /\left[\mathrm{Na}^{+}\right]\right\}_{\text {sea salt }}$ is ratio of these species measured in sea water [66]. Furthermore, marine enrichment factors of the anions with respect to $\mathrm{Na}$ are estimated as follows: $E F=\left[\mathrm{X} / \mathrm{Na}^{+}\right]_{\text {rain }} /\left[\mathrm{X} / \mathrm{Na}^{+}\right]_{\text {seawater }}$ where $\mathrm{X}$ is the ion of interest.

\subsubsection{Wet deposition flux (WDF)}

The volume-weighted mean concentrations (VWM) of trace metals $\left(\mathrm{mg} \mathrm{L}^{-1}\right)$ and wet deposition fluxes $\left(\mathrm{mgm}^{-2}\right)$ were determined using Eqs. (1) and (2), respectively:

$$
C_{V W M}=\sum_{i=1}^{n}(C i \times P i) / \sum_{i=1}^{n} P i
$$

$W D F=C_{V W M} \times P_{t} / 1000$

where $\mathrm{C}_{\mathrm{VWM}}$ is the concentration of $\mathrm{VWM}, \mathrm{Ci}\left(\mathrm{mg} \mathrm{L}^{-1}\right)$ are the concentrations of the measured TE, $\mathrm{Pi}(\mathrm{mm})$ are the rainfall amount of individual precipitation event, and WD is the wet deposition.

WDF refers to the monthly/seasonal/annual wet deposition flux expressed in $\mathrm{mgm}^{-2}$, which is calculated by multiplying the $C_{\mathrm{vwm}}\left(\mathrm{mg} \mathrm{L}^{-1}\right)$ by the volume of monthly/seasonal/annual rainfall amount in $\mathrm{mm}$. For the present study, seasonal $P_{t}$ in $\mathrm{mm}$ will be for the months of July to October 2019 , i.e. those during which the samples were collected and annual $P_{t}$ for the entire year $[18,127]$. Precipitation data were obtained from archive of Regional Meteorological Centre Kolkata, via the online portal at http://imdko Ikata.gov.in/.

\section{Results and discussion}

\section{1 $\mathrm{PM}_{10}$ concentration and trace metal composition}

The $\mathrm{PM}_{10}$ concentrations ranged between 42 and $69 \mu \mathrm{g} /$ $\mathrm{m}^{3}$ (average $56 \pm 9 \mu \mathrm{g} / \mathrm{m}^{3}, 1 \mathrm{SD}$ ) during the sampling period which is well within the National Ambient Air Quality Standards (NAAQS) [121] prescribed value of $100 \mu \mathrm{g} / \mathrm{m}^{3}$ for $24 \mathrm{~h}$.

The overall trend of the average elemental composition of $\mathrm{PM}_{10}$ is $(\mathrm{Na}, \mathrm{Al}, \mathrm{Ca}, \mathrm{Fe}$ and $\mathrm{Mg})>100 \mathrm{ng} / \mathrm{m}^{3},(\mathrm{Zn}$, $\mathrm{Mn}$ and $\mathrm{Pb})>10 \mathrm{ng} / \mathrm{m}^{3}$, and $(\mathrm{Ni}, \mathrm{Cu}, \mathrm{V}, \mathrm{Cr}$ and $\mathrm{Cd})<5 \mathrm{ng} /$ $\mathrm{m}^{3}$ (Fig. 2, Table 1). Concentrations reported in this study
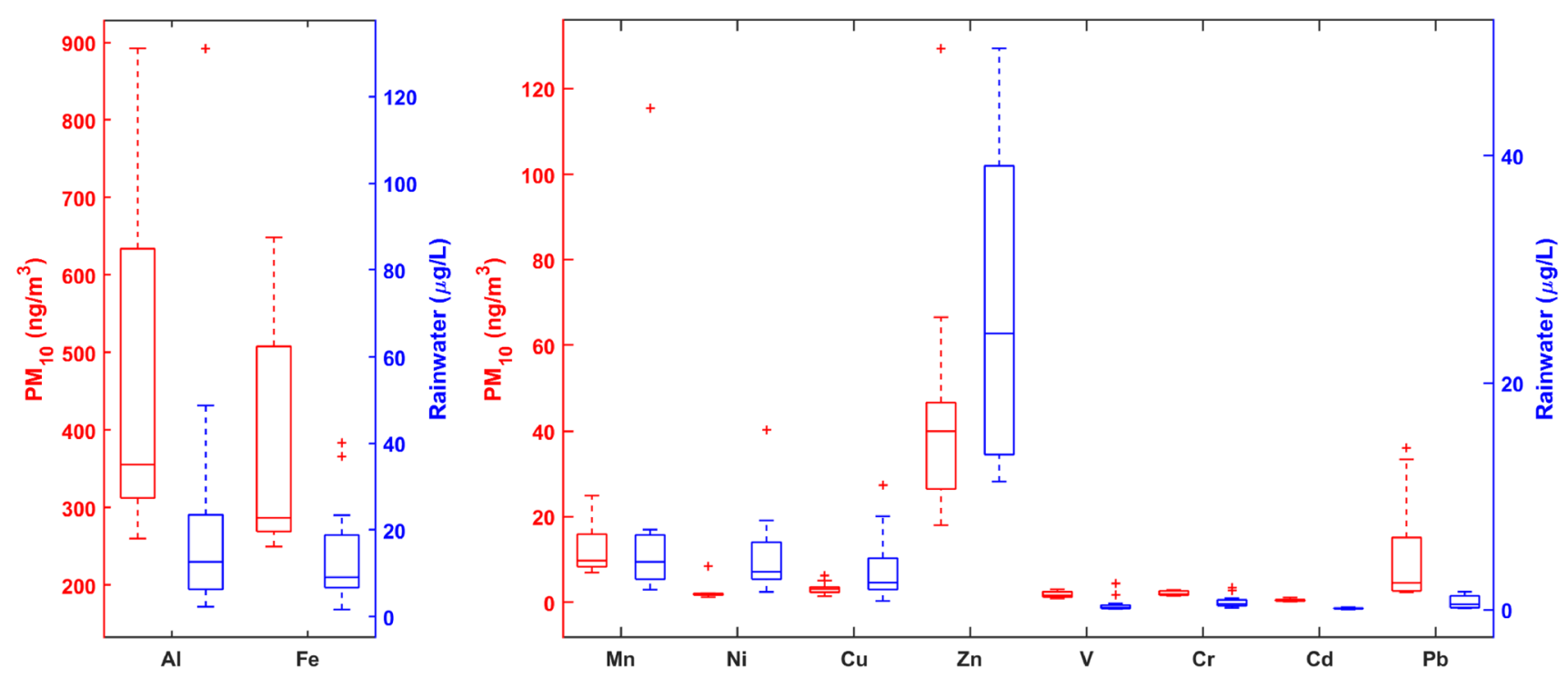

Fig. 2 Box plot of metal concentrations in $\mathrm{PM}_{10}$ (red box) and rainwater (blue box) from Kolkata 
Table 1 Summary statistics of major ions and trace metals in rainwater $(n=13)$ and $\mathrm{PM}_{10}(n=10)$ measured during the study period

\begin{tabular}{|c|c|c|c|c|c|c|c|c|c|c|c|c|c|}
\hline RAINWATER & Unit & Mean & $1 S D$ & Median & Min & Max & AEROSOL & Unit & Mean & $1 S D$ & Median & Min & $\operatorname{Max}$ \\
\hline $\mathrm{pH}$ & & 6.8 & 0.74 & 7.0 & 5.4 & 8.0 & $\mathrm{PM}_{10}$ & $\mu \mathrm{g} / \mathrm{m}^{3}$ & 56 & 9.3 & 56 & 42 & 69 \\
\hline Conductivity & $\mu \mathrm{S} / \mathrm{cm}$ & 55 & 46 & 38 & 13 & 188 & & & & & & & \\
\hline $\mathrm{Cl}^{-}$ & $\mu e q / L$ & 68 & 35 & 61 & 18 & 126 & & & & & & & \\
\hline $\mathrm{NO}_{3}^{-}$ & $\mu e q / L$ & 202 & 190 & 136 & 20 & 614 & & & & & & & \\
\hline $\mathrm{SO}_{4}{ }^{2-}$ & $\mu e q / L$ & 65 & 63 & 40 & 25 & 218 & & & & & & & \\
\hline $\mathrm{Na}^{+}$ & $\mu \mathrm{g} / \mathrm{L}$ & 1381 & 619 & 1303 & 393 & 2440 & $\mathrm{Na}$ & $\mathrm{ng} / \mathrm{m}^{3}$ & 496 & 274 & 517 & 117 & 855 \\
\hline $\mathrm{Ca}^{2+}$ & $\mu \mathrm{g} / \mathrm{L}$ & 1231 & 1475 & 514 & 152 & 4597 & $\mathrm{Ca}$ & $\mathrm{ng} / \mathrm{m}^{3}$ & 441 & 178 & 417 & 217 & 731 \\
\hline $\mathrm{Mg}^{2+}$ & $\mu \mathrm{g} / \mathrm{L}$ & 198 & 127 & 162 & 52 & 470 & $\mathrm{Mg}$ & $\mathrm{ng} / \mathrm{m}^{3}$ & 188 & 81 & 164 & 81 & 372 \\
\hline $\mathrm{Al}$ & $\mu \mathrm{g} / \mathrm{L}$ & 24 & 35 & 13 & 2.3 & 131 & $\mathrm{Al}$ & $\mathrm{ng} / \mathrm{m}^{3}$ & 459 & 206 & 356 & 260 & 893 \\
\hline $\mathrm{Fe}$ & $\mu \mathrm{g} / \mathrm{L}$ & 14 & 12 & 9.1 & 1.6 & 40 & $\mathrm{Fe}$ & $\mathrm{ng} / \mathrm{m}^{3}$ & 385 & 159 & 287 & 250 & 648 \\
\hline $\mathrm{Mn}$ & $\mu \mathrm{g} / \mathrm{L}$ & 7.2 & 11 & 4.2 & 1.8 & 44 & $\mathrm{Mn}$ & $\mathrm{ng} / \mathrm{m}^{3}$ & 12 & 6.0 & 9.7 & 6.9 & 25 \\
\hline V & $\mu \mathrm{g} / \mathrm{L}$ & 0.45 & 0.65 & 0.19 & 0.08 & 2.3 & V & $\mathrm{ng} / \mathrm{m}^{3}$ & 1.8 & 0.73 & 1.6 & 0.85 & 3.0 \\
\hline $\mathrm{Cr}$ & $\mu \mathrm{g} / \mathrm{L}$ & 0.71 & 0.55 & 0.51 & 0.18 & 1.9 & $\mathrm{Cr}$ & $\mathrm{ng} / \mathrm{m}^{3}$ & 2.0 & 0.54 & 1.9 & 1.4 & 2.8 \\
\hline $\mathrm{Ni}$ & $\mu \mathrm{g} / \mathrm{L}$ & 4.8 & 3.8 & 3.4 & 1.6 & 16 & $\mathrm{Ni}$ & $\mathrm{ng} / \mathrm{m}^{3}$ & 2.4 & 2.1 & 1.8 & 1.1 & 8.4 \\
\hline $\mathrm{Cu}$ & $\mu \mathrm{g} / \mathrm{L}$ & 3.7 & 3.2 & 2.4 & 0.79 & 11 & $\mathrm{Cu}$ & $\mathrm{ng} / \mathrm{m}^{3}$ & 3.2 & 1.4 & 3.0 & 1.4 & 6.3 \\
\hline $\mathrm{Zn}$ & $\mu \mathrm{g} / \mathrm{L}$ & 26 & 14 & 24 & 11 & 49 & $\mathrm{Zn}$ & $\mathrm{ng} / \mathrm{m}^{3}$ & 47 & 32 & 40 & 18 & 129 \\
\hline $\mathrm{Cd}$ & $\mu \mathrm{g} / \mathrm{L}$ & 0.12 & 0.06 & 0.12 & 0.03 & 0.22 & $\mathrm{Cd}$ & $\mathrm{ng} / \mathrm{m}^{3}$ & 0.40 & 0.29 & 0.31 & 0.10 & 1.0 \\
\hline $\mathrm{Pb}$ & $\mu \mathrm{g} / \mathrm{L}$ & 0.68 & 0.54 & 0.48 & 0.14 & 1.6 & $\mathrm{~Pb}$ & $\mathrm{ng} / \mathrm{m}^{3}$ & 12 & 13 & 4.5 & 2.3 & 36 \\
\hline
\end{tabular}

are less than those reported in previous studies from Kolkata $[25,57]$. Generally, the pollution levels have a seasonality and are minimum during the monsoon due to washout effect. The previous studies reported trace elements in PM during winter [25] when pollution is highest due to thermal inversion and annual average [57], which is generally higher than monsoon minima. Hence, absolute concentrations are inadequate to understand the sources, and thus we use the crustal enrichment factor (EF).

As per the EF calculations, any element with natural origin should have $\mathrm{EF} \sim 1$. However, to account for the local variability of upper continental crustal composition which forms the immediate precursor of the aerosol metals, EF $\leq 10$ is, considered to have a natural origin [25-27, 57, 59]. In $\mathrm{PM}_{10}, \mathrm{Na}, \mathrm{Mg}, \mathrm{Al}, \mathrm{Ca}, \mathrm{V}, \mathrm{Cr}, \mathrm{Mn}$ and Fe have $\mathrm{EF}<10$ indicating natural origin. $\mathrm{Ni}$ and $\mathrm{Cu}$ have EF between 10 and 100 indicating moderate enriched by anthropogenic sources. Very high EF (EF > 100) of $\mathrm{Pb}, \mathrm{Cd}$ and $\mathrm{Zn}$ are most likely associated with industrial, high-temperature combustion and vehicular emissions (Fig. 3b). The general trend of EFs observed in our study is consistent with those reported from Kolkata by [25] indicating the presence and similar intensity of anthropogenic sources. Though EF can differentiate between crustal and anthropogenic origins, source apportionment of PM is difficult to achieve solely based on EF and elemental concentrations. Thus, principal component analysis (PCA) and elemental ratios are used to better understand the anthropogenic sources of the metals.
As the objective of the study is to understand sources of trace metals in rainwater, we exclude the major ions in rainwater such as $\mathrm{Na}, \mathrm{Ca}$ and $\mathrm{Mg}$ from $\mathrm{PCA}$ analysis in both the $\mathrm{PM}_{10}$ and rainwater samples. Four factors can explain $92 \%$ of the total variation in the $\mathrm{PM}_{10}$ metal dataset (Table S2, Fig. 4). Communalities of all metals ranged between 0.85 and 0.99 which is an indication of satisfactory apportionment of each element to the identified factors. Physical interpretation of each factor or source was based on its association with strong loading of marker elements, typically emitted from that source.

The first factor is associated with $\mathrm{Al}, \mathrm{Fe}, \mathrm{Mn}$, and $\mathrm{Cr}$ and can explain $41.8 \%$ of the total variance. Al and Fe are typically crustal metals, and all the metals have $E F<10$. Hence factor 1 represents crustal source [5, 21, 113].

Factor, associated with $\mathrm{Ni}, \mathrm{Cd}$ and $\mathrm{Zn}$ explains $27.8 \%$ of the total variance. The largest sources of atmospheric $\mathrm{Ni}$ are coal and liquid fuels consumption [118]. Other minor sources include non-ferrous metal smelting, cement production, brick production, glass manufacturing. The ferrous and non-ferrous metal industries and fuel combustion are estimated to account for the largest emissions of atmospheric $\mathrm{Cd}[52,85]$. $\mathrm{Cd}$ has the highest EF and can also originate from the production and recycling of $\mathrm{Ni}-\mathrm{Cd}$ batteries [117]. Major anthropogenic sources of $\mathrm{Zn}$ are coal combustion and industrial activities $[75,84]$. Hence factor 2 represents coal combustion and industrial emissions.

The third factor, with marker elements $\mathrm{Pb}$ and $\mathrm{V}$, explains $13 \%$ of the total variance. Both $\mathrm{Pb}$ and $\mathrm{V}$ are characteristics of road traffic or vehicular emissions $[5,42,71]$. 
Fig. 3 A) Concentration trends of the measured elements in $\mathrm{PM}_{10}$ and rainwater. $\mathrm{B}$ ) Enrichment factors (EF) of metals, calculated using Al as reference. $\mathrm{EF}$ is calculated with respect to average upper continental crust (UCC) composition from [93]. Metals with values of EFs $<10$ have crustal sources, and those with values of EFs $>10$ indicate anthropogenic influence

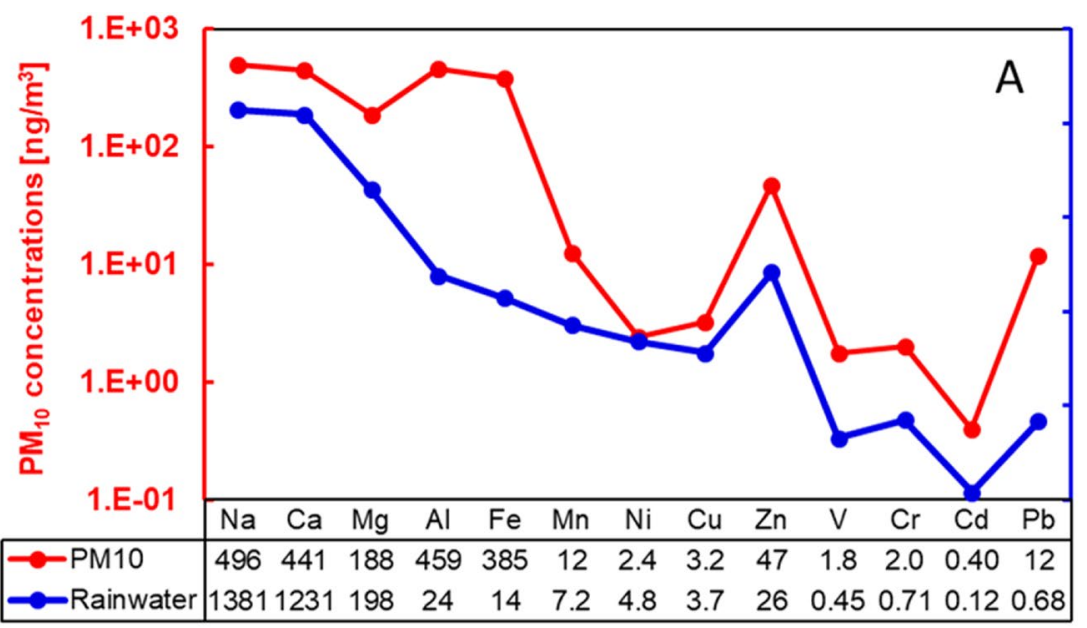

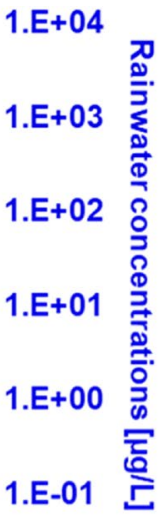
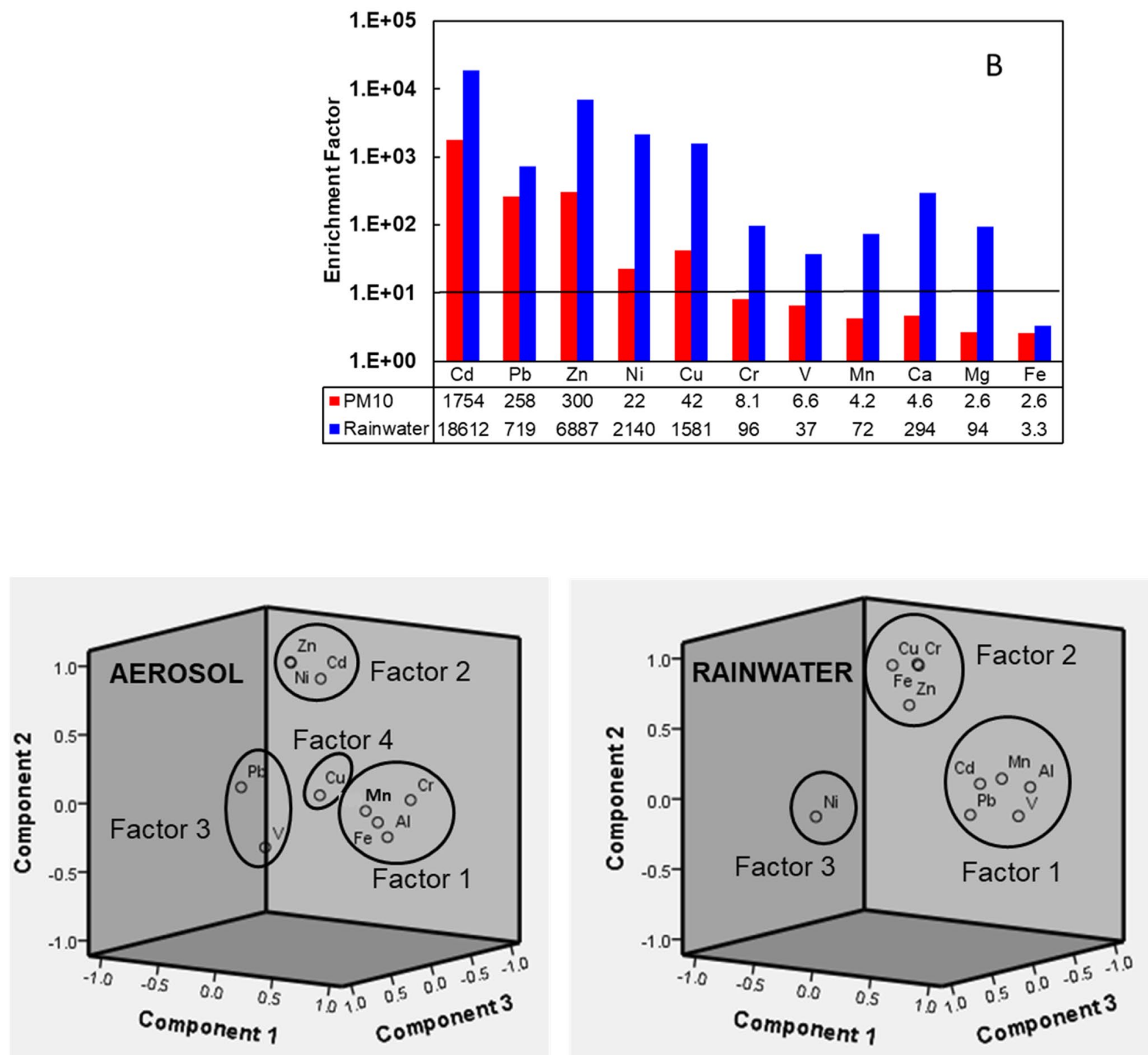

Fig. 4 Principal component analysis (PCA) loading three-dimensional plot for 10 trace elements in aerosol $\left(\mathrm{PM}_{10}\right)$ and rainwater 
Though leaded gasoline was completely phased out from India in the year 2000, present-day diesel and unleaded gasoline still contain trace amounts of $\mathrm{Pb}$ [22]. The large fleet of vehicles on city roads magnify $\mathrm{Pb}$ emission to the atmosphere. $\mathrm{V} / \mathrm{Pb}$ ratios can differentiate vehicular sources from coal combustion and industrial emissions. Coal is generally enriched in $\mathrm{V}$ ( $\mathrm{mg} / \mathrm{g}$ level) resulting in $\mathrm{V} / \mathrm{Pb}$ ratio of $>1$, whereas non-coal burning industrial sources have $\mathrm{V} / \mathrm{Pb}$ ratio $<<1[40]$. $\mathrm{V} / \mathrm{Pb}$ ratio of vehicle exhaust is in between and is usually $<1$. The Kolkata aerosols have average $\mathrm{V} / \mathrm{Pb}$ ratios of $0.30 \pm 0.20,1 \mathrm{SD}$ (range $0.08-0.59$ ), indicative of vehicle exhaust emission.

Finally, the fourth factor, primarily loaded with $\mathrm{Cu}$, explains $9.4 \%$ of the total variance. Fossil fuel combustion, commercial metallurgical processes and waste incineration are the major sources of atmospheric Cu emission [63].

\section{$3.2 \mathrm{pH}$ and conductivity of rainwater}

The $\mathrm{pH}$ of the rainwater from this study ranged from 5.4 to 8.0 (average $6.8 \pm 0.74,1 S D$ ). Out of 13 rainwater samples, approximately $15 \%$ were acidic $(\mathrm{pH}<5.61), 15 \%$ were slightly acidic ( $\mathrm{pH} 5.6-6.5)$ and $54 \%$ of the samples were alkaline with $\mathrm{pH}>7$. The $\mathrm{pH}$ of natural precipitation in pristine environment is 5.6 and is controlled by interaction between water droplets and atmospheric $\mathrm{CO}_{2}$ [19]. However, in polluted settings, the $\mathrm{pH}$ of rainwater is mainly regulated by the abundance of acids forming chemical species such as $\mathrm{SO}_{4}{ }^{2-}$ and $\mathrm{NO}_{3}{ }^{-}$, and basic gas such as $\mathrm{NH}_{3}$. Soil dust containing $\mathrm{Ca}^{2+}, \mathrm{Mg}^{2+}$ and $\mathrm{K}^{+}$can balance acidification, due to their buffering capacity [60, $72,99,101,110,120]$. The average $\mathrm{pH}$ of the present study $(\mathrm{pH}=6.8)$ is slightly higher than the Indian average of 6.5 [17]. The $\mathrm{pH}$ range of the present study is comparable with those reported in earlier studies from Kolkata [17] but less alkaline than those reported by [68] (Table 2). The sulphate ion showed strong negative correlation with $\mathrm{pH}$ $\left(r^{2}=-0.8\right)$ but not the nitrate. The almost neutral $\mathrm{pH}$ of the precipitation is due to the neutralization caused by different cations. When the sum of $\left(\left[\mathrm{Ca}^{2+}\right]+\left[\mathrm{Mg}^{2+}\right]\right)$ is fitted against $\left[\mathrm{SO}_{4}{ }^{2-}\right]$, the correlation coefficient is 0.73 , indicating that $\mathrm{Ca}$ and $\mathrm{Mg}$ carbonate is the major neutralizing base [5]. Slightly alkaline $\mathrm{pH}$ has been reported from many other cities and states of India as well as places around Asia (Table 2). In general, Indian precipitation has higher $\mathrm{pH}$ than natural rainwater resulting from high loading of alkaline rich atmospheric particulate matter though acid rain has been reported from coal mining city of Dhanbad and the national capital of Delhi due to the influence of $\mathrm{SO}_{4}{ }^{2-}$ ions $[91,109]$.

Conductivity in the present study ranged from 12.6 to $188 \mu \mathrm{S} / \mathrm{cm}$ (average $55 \pm 46 \mu \mathrm{S} / \mathrm{cm}, 1 \mathrm{SD}$ ). Low conductivity in precipitation is an indicator of good environmental quality in the atmosphere [125]. The common conductivity range of precipitation is $5-1000 \mu \mathrm{S} / \mathrm{cm}$ [4]. There were two previous studies from Kolkata. One reported similar conductivity $(47.87 \mu \mathrm{S} / \mathrm{cm})$ [17], and the other study reported much higher conductivity $(370 \pm 297 \mu \mathrm{S} / \mathrm{cm})$ that was attributed to industrial emissions of cations and anions in the megacity atmosphere [68]. The conductivity of the present study is compared to other Indian cities given in Table 2. Precipitation conductivity is attributed primarily to the total soluble ionic components present in the rainwater hence reflecting the impact of atmospheric particulate matter on rainwater chemistry [80]. In this study, the conductivity strongly correlates $\left(r^{2}=0.85\right)$ with Ca most likely due to presence of $\mathrm{CaCO}_{3}$ as a significant solute [3].

\subsection{Chemical composition of rainwater}

Inorganic composition of rainwater comprises the major anions $\left(\mathrm{Cl}^{-}, \mathrm{NO}_{3}{ }^{-}, \mathrm{SO}_{4}{ }^{2-}\right), \mathrm{NH}_{4}{ }^{+}$from anthropogenic emissions, major elements ( $\mathrm{Ca}, \mathrm{Mg}, \mathrm{Na}, \mathrm{K})$ and trace metals. In this study, $\mathrm{K}$ and $\mathrm{NH}_{4}{ }^{+}$were not measured. Concentrations in rainwater follow the order of $(\mathrm{Na}$ and $\mathrm{Ca})>1000 \mu \mathrm{g} / \mathrm{L}$, $\mathrm{Mg}>100 \mu \mathrm{g} / \mathrm{L}$, (Al, Fe and $\mathrm{Zn})>10 \mu \mathrm{g} / \mathrm{L}$ and $(\mathrm{Mn}, \mathrm{Ni}, \mathrm{Cu}, \mathrm{V}$, $\mathrm{Cr}, \mathrm{Cd}$ and $\mathrm{Pb})<10 \mu \mathrm{g} / \mathrm{L}$ (Fig. 2).

The marine and non-marine contributions of the anions $\mathrm{Cl}^{-}$and $\mathrm{SO}_{4}{ }^{2-}$ were determined. The ratios of $\mathrm{Cl}^{-}$and $\mathrm{SO}_{4}{ }^{2-}$ with respect to $\mathrm{Na}^{+}$in sea water are 1.16 and 0.125 , respectively [66]. Average $\mathrm{Cl}^{-} / \mathrm{Na}^{+}$ratio of rainwater samples $(1.12 \pm 0.17)$ is similar to sea water ratio of 1.16. Significant correlation between $\mathrm{Cl}^{-}$and $\mathrm{Na}^{+}(r=0.96)$ confirmed sea salt origin. Average $\mathrm{SO}_{4}{ }^{2-} / \mathrm{Na}^{+}$ratio of rainwater samples $(1.132 \pm 0.90)$ is higher than sea water. Calculations show sea salt fraction of $\mathrm{SO}_{4}{ }^{2-}$ is only $12 \%$. Furthermore, marine enrichment factor of $\mathrm{Cl}^{-}$is 1 indicating marine source and that of $\mathrm{SO}_{4}{ }^{2-}$ is 9 indicating contribution of non-marine sources. The non-sea salt fraction of $\mathrm{SO}_{4}{ }^{2-}$ may be sourced from soil dust containing gypsum, pyrite or may be derived from anthropogenic processes, primarily combustion [10, 35, 65, 83, 112].

Removal of aerosols by wet deposition occurs primarily by two mechanisms, below-cloud scavenging and withincloud scavenging [43]. For below cloud scavenging, trace metal composition of the ambient aerosol controls the composition of rainwater. Relative abundance of metals in rainwater depends on emission sources and solubility of metals. The general concentration trend of the major elements in rainwater followed the aerosol $\mathrm{Na}, \mathrm{Ca}, \mathrm{Mg}$ trend (Fig. 3a). The overall concentration trend of the metals $\mathrm{Cu}$, $\mathrm{Zn}, \mathrm{Cd}, \mathrm{V}, \mathrm{Cr}$ and $\mathrm{Pb}$ follows the trend in $\mathrm{PM}_{10}$ indicating at least part of the metals are derived from aerosol leaching (Fig. 3a). However, $\mathrm{Al}$ and Fe do not follow the trend indicating limited leaching of these two elements from 
Table 2 Comparison of $\mathrm{pH}$ of rainwater of the sampling site in Kolkata with some other selected sites of India and the world

\begin{tabular}{|c|c|c|c|}
\hline Site & $\mathrm{pH}$ & Conductivity $(\mu \mathrm{S} / \mathrm{cm})$ & Reference \\
\hline Kolkata, India & $6.81 \pm 0.74$ & $55 \pm 46$ & Present Study \\
\hline Kolkata, India & 6.77 & 48 & [17] \\
\hline Kolkata, India & $7.23 \pm 0.68$ & $370 \pm 30$ & [68] \\
\hline Delhi, India & 5.70 & - & [91] \\
\hline Dhanbad, India & $5.37 \pm 0.78$ & $27 \pm 26$ & [109] \\
\hline Nagpur, India & $6.30 \pm 0.30$ & - & [97] \\
\hline Roorkee, India & 7.05 & - & [53] \\
\hline Mumbai, India & 5.70 & - & [88] \\
\hline Comba, South Goa & $6.25 \pm 0.28$ & - & [39] \\
\hline Bongaigaon, India & 5.68 & 25 & {$[17]$} \\
\hline BGR Township, India & 6.01 & 22 & [17] \\
\hline Dolaigaon, India & 5.35 & 30 & [17] \\
\hline Irongmara, India & 5.58 & 24 & [17] \\
\hline Kharagpur, India & 6.06 & 11 & [17] \\
\hline Varanasi, India & 5.72 & 18 & [119] \\
\hline Ballia, India & 6.03 & 24 & [119] \\
\hline Kanpur, India & 5.81 & 26 & [119] \\
\hline Manali, India & 5.76 & 29 & [119] \\
\hline Meerut, India & 5.65 & 30 & [119] \\
\hline Gorakhpur, India & 5.44 & 34 & [119] \\
\hline Delhi, India & 5.81 & 39 & [119] \\
\hline Kurukshetra, India & 5.61 & 44 & [119] \\
\hline Tharamani, India & $7.14 \pm 0.64$ & $75 \pm 24$ & [68] \\
\hline Tirunelveli, India & $7.63 \pm 0.41$ & $403 \pm 702$ & {$[68]$} \\
\hline Kakinada, India & $7.53 \pm 0.98$ & $111 \pm 702$ & [68] \\
\hline Belgaum, India & $7.53 \pm 0.24$ & $134 \pm 29$ & {$[68]$} \\
\hline Bangalore, India & $6.42 \pm 1.32$ & $82 \pm 62$ & {$[68]$} \\
\hline Patna, India & $6.93 \pm 0.096$ & $51 \pm 7$ & {$[68]$} \\
\hline Sagar, India & $7.40 \pm 0.47$ & $89 \pm 52$ & {$[68]$} \\
\hline Lucknow, India & $7.36 \pm 0.33$ & $95 \pm 66$ & [68] \\
\hline Jammu, India & $7.07 \pm 0.48$ & $153 \pm 66$ & {$[68]$} \\
\hline Gangotri, India & 6.30 & 8 & {$[68]$} \\
\hline Dabrani, India & $5.90 \pm 0.21$ & $59 \pm 68$ & [68] \\
\hline Uttarkashi, India & $6.83 \pm 0.92$ & $88 \pm 63$ & {$[68]$} \\
\hline Devprayag, India & $6.25 \pm 0.21$ & $37 \pm 24$ & [68] \\
\hline Danum Valley Malaysia & 5.17 & 8.30 & [114] \\
\hline Loess plateau, Northwest China & $7.82 \pm 0.43$ & $124 \pm 67.30$ & [128] \\
\hline $\begin{array}{l}\text { Nanping Mangdang Mountain, East- } \\
\text { ern China }\end{array}$ & 4.81 & 20 & [21] \\
\hline Guangzhou, South China & 4.49 & - & [16] \\
\hline Beijing, China & 5.12 & - & [128] \\
\hline
\end{tabular}

aerosol. Natural sources of $\mathrm{Al}$ and $\mathrm{Fe}$ in aerosol are crustal dust, and these two elements are mostly locked inside aluminosilicate structures [93] that are difficult to leach in rainwater. The sampling location is on the alluvium of the Indo Gangetic Plain (IGP). The common aluminosilicates that are found in the IGP soil are illite/mica, smectite, kaolinite and feldspars. The EFs of trace elements in rainwater of Kolkata are shown in Fig. $3 \mathrm{~b}$ and compared with the EF of $\mathrm{PM}_{10}$ trace elements. Out of all the trace elements measured, $\mathrm{Fe}$ is the only non-enriched element with $\mathrm{EF}<10$. The major element $\mathrm{Ca}$ and $\mathrm{Mg}$ in rainwater have high $\mathrm{EF}$ indicating anthropogenic influences. In cities, the sources of $\mathrm{Ca}$ and $\mathrm{Mg}$ can be cement from construction dust and road dust because of the abundance of alkaline materials in road coverings [37]. $\mathrm{V}, \mathrm{Mn}$, and $\mathrm{Cr}$ are moderately enriched with EF between 10 and $100 . \mathrm{Cu}, \mathrm{Ni}, \mathrm{Zn}, \mathrm{Pb}$ and 
Cd were highly enriched with $\mathrm{EF}>100$ indicating strong anthropogenic sources.

$\mathrm{Cu}, \mathrm{Ni}, \mathrm{Zn}, \mathrm{Pb}$ and $\mathrm{Cd}$ have $\mathrm{EF}>10$ in $\mathrm{PM}_{10}$ collected in between rain events and were identified to have anthropogenic sources related to non-ferrous metal industry, waste incineration and coal combustion [63, 84, 85]. V, Mn, Co and $\mathrm{Cr}$ in aerosol have $\mathrm{EF}$ between 4 and 9 . However, their $\mathrm{EF}$ in rainwater increases to greater than 10 but less than 100 in rainwater.

Figure 4 presents the three dissolved trace metal clusters for rainwater during monsoon period. Varimax-rotated PCA identified three sources of trace metals in the rainwater and can explain $79 \%$ of the variance in the data (Table S3). The first factor explains $38.6 \%$ variance and is loaded with crustal element such as $\mathrm{Al}$, and the rest are anthropogenic metals such as $\mathrm{Mn}, \mathrm{V}, \mathrm{Cd}$ and $\mathrm{Pb}$. Factor 1 can be attributed to vehicular emission and road dust [107]. Factor 2 accounts for $27 \%$ of the variance and has strong loadings of $\mathrm{Fe}, \mathrm{Zn}, \mathrm{Cu}$ and $\mathrm{Cr}$ and is possibly soil dust mixed with industrial emission. Factor 3 explains $13.7 \%$ variance and has strong loading of $\mathrm{Ni}$ and moderate loading of $\mathrm{Zn}$ and is possibly related to coal combustion emission [84].

VWM and average concentrations of trace elements in our study were compared with those reported from India and worldwide (Table 3). Selected worldwide stations are either large urban centres and/or stations close to the coast like Kolkata. A remote station in Lhasa, Tibet, is also chosen for comparison. Trace elements in two successive rain events from the Indian city of Lucknow reported higher concentrations of $\mathrm{Cu}, \mathrm{Zn}, \mathrm{Cr}, \mathrm{Cd}$ and $\mathrm{Pb}$. This is possibly because concentrations of these elements are several times higher in Lucknow $\mathrm{PM}_{10}$ compared to Kolkata during monsoon [103]. However, the trace element concentrations in the Kolkata rainwater are in the same order of magnitude with those reported from global rainfall data over urban centres. The concentrations of Ca were higher than those reported from both the stations in Brazil and Europe. The high concentration of $\mathrm{Ca}$ in Kolkata rain is primarily due to the influence of soil dust and endless constructions which contains large fractions of $\mathrm{CaCO}_{3}$. The concentration of marine elements such as $\mathrm{Na}$ and $\mathrm{Mg}$ in rainwater of Kolkata is higher than most of the compared cities but lower than that of Coastal Station in Western Europe and comparable with Northern \& Southern Jordan $[3,5,28]$. The Bay of Bengal coast is approximately $125 \mathrm{~km}$ south of Kolkata and presumably influences the rainwater composition. Concentrations of crustal elements such as Al and Fe measured in Kolkata precipitation are low relative to other sites. Anthropogenic elements such as $\mathrm{Zn}$ and $\mathrm{Pb}$ were significantly lower than Kolkata rainwater compared to cities in Greece, Iran, Jordan, China and Lucknow. Pb shows large variation in the global dataset. In Jordan, high concentrations of $\mathrm{Pb}$ are attributed to biomass burning and industrial activities $[3,5]$. High $\mathrm{Pb}$ was also reported from China and Singapore. While $\mathrm{Pb}$ in China was due to

Table 3 The volume-weighted mean (VWM) concentrations of major ions and trace metals $(\mu \mathrm{g} / \mathrm{L})$ in this study are compared to those obtained from other parts of the world

\begin{tabular}{|c|c|c|c|c|c|c|c|c|c|c|c|c|c|c|c|}
\hline Location & & $\mathrm{Na}$ & $\mathrm{Ca}$ & $\mathrm{Mg}$ & $\mathrm{Al}$ & $\mathrm{Fe}$ & $\mathrm{Mn}$ & v & $\mathrm{Cr}$ & $\mathrm{Ni}$ & $\mathrm{Cu}$ & $\mathrm{Zn}$ & $\mathrm{Cd}$ & $\mathrm{Pb}$ & Reference \\
\hline Kolkata, India & VWM & 1686 & 1748 & 275 & 46 & 19 & 14 & 0.76 & 0.82 & 3.7 & 4.1 & 31 & 0.14 & 1.0 & This study \\
\hline Kolkata, India & Average & 1381 & 1231 & 198 & 24 & 14 & 7.2 & 0.45 & 0.71 & 4.8 & 3.7 & 26 & 0.12 & 0.68 & This study \\
\hline Lucknow, India (1st rainfall) & Average & - & - & - & - & - & 2.0 & - & 121 & - & 1.0 & 122 & 11 & 33 & [103] \\
\hline Lucknow, India (2nd rainfall) & Average & - & - & - & - & - & 3.0 & - & 17 & - & 10 & 85 & 46 & 62 & [103] \\
\hline Acegua, Brazil ${ }^{a}$ & Average & 349 & 156 & 66 & - & 2.4 & 2.2 & - & 0.15 & 0.64 & 0.30 & 10 & 0.06 & 0.13 & [117] \\
\hline Tres lagoas, Brazil ${ }^{a}$ & Average & 206 & 181 & 37 & - & 2.9 & 1.6 & - & 0.07 & 0.02 & 0.50 & 6.8 & 0.01 & 0.15 & [117] \\
\hline Athens, Greece ${ }^{b}$ & Average & - & - & - & 5.8 & 4.4 & 3.6 & - & 1.3 & 4.14 & 15 & 33 & 0.20 & 0.88 & {$[56]$} \\
\hline Shiraz, Iran ${ }^{a, b}$ & Average & - & - & - & 430 & 306 & 24 & - & 1.6 & 4.12 & 13 & 63 & - & 10 & [76] \\
\hline Pensacola, Florida ${ }^{b}$ & VWM & 985 & - & & 53 & 26 & 1.1 & 0.27 & 0.10 & 0.37 & 4.6 & 2.2 & 0.01 & 0.31 & [69] \\
\hline Northern Jordan ${ }^{a}$ & Average & 1150 & 2166 & 373 & 382 & 92 & 2.1 & 4.2 & 0.77 & 2.6 & 3.1 & 6.5 & 0.42 & 2.6 & {$[5]$} \\
\hline Southern Jordan ${ }^{a}$ & Average & 1614 & 2513 & 734 & 115 & 87 & 20 & - & - & - & 36 & 33 & - & 39 & [3] \\
\hline Singapore ${ }^{b}$ & VWM & - & - & - & 18 & 24 & 2.7 & 3.5 & 1.6 & 3.9 & - & - & 0.33 & 7.2 & [49] \\
\hline Tangshan, Northern China ${ }^{a}$ & VWM & - & - & - & 248 & 291 & 28 & 1.4 & 1.0 & 1.4 & 5.4 & 89 & 0.30 & 18 & {$[130]$} \\
\hline Nanjing, China ${ }^{a}$ & Average & - & - & - & 113 & 19 & 24 & 4.6 & 11 & 1.4 & - & 28 & 3.30 & 13 & [116] \\
\hline Coastal Station in Western Europe ${ }^{b}$ & VWM & 13794 & 461 & 827 & - & - & - & - & - & - & 0.70 & 16 & 0.10 & 2 & {$[28]$} \\
\hline Tibet, Lhasac ${ }^{c}$ & VWM & - & - & - & 131 & 221 & 7.7 & 0.31 & 0.43 & 0.58 & 1.7 & 14 & 0.03 & 1.6 & [43] \\
\hline
\end{tabular}

a Polluted cities

b Coastal location

c Remote location 
industrial emission, high $\mathrm{Pb}$ in Singapore rain was due to atmospheric scavenging of gasoline $\mathrm{Pb}$ released from neighbouring Indonesia. Interestingly, though India is the second largest emitter of atmospheric $\mathrm{Pb}$ in Asia, after China [70], $\mathrm{Pb}$ concentration in rainwater is $<1 \mathrm{ppb}$ indicating low solubility of atmospheric $\mathrm{Pb}$ over Kolkata and hence limited bioavailability of the toxic metal. Most of the metals (except the crustal elements $\mathrm{Al}$ and $\mathrm{Fe}$ ) in Kolkata are higher than in Tibetan rainfall as expected, but interestingly, $\mathrm{Pb}$ concentrations are comparable and only $\sim 0.5$ times higher in Kolkata rain.

\subsection{Comparison of precipitation chemistry with groundwater and surface water}

With increasing population pressure, there is growing reliance on groundwater for farming and drinking purposes. Human activity has threatened freshwater reserve by polluting and depleting groundwater reserve by overdrawing [123]. Rainwater is relatively free from impurities and may be one of the alternative sources of drinking water.

The drinking water standards of India consist of several criteria such as: (1) perceptible parameters and inorganic constituents, (2) organic substances, (3) pesticides, (4) disinfectant and disinfectant by-products, (5) radioactive constituents, and (6) micro-organisms [46]. The present study focuses only on the inorganic components of the rainwater. In Table 4, we have compared rainwater chemistry with other sources of drinking water such as untreated groundwater and river water from India. Kolkata rainwater meets the Indian and the WHO standards for drinking water, while the concentrations of toxic metals such as $\mathrm{Pb}$ and $\mathrm{Ni}$ of river and groundwater are higher than the guideline values. $\mathrm{Pb}$ is long known to affect physical or mental development in infant and children and causes high blood pressure and kidney problems in adults [15, 20]. $\mathrm{Ni}$ is a well-known human carcinogen that affects the activity of a-tocopherol, the most common lipid soluble antioxidant in human body [58]. The concentration of major ions such as $\mathrm{Na}, \mathrm{Ca}$ and $\mathrm{Mg}$ is higher in river and groundwater compared to rainwater, but they are within the limits prescribed by WHO and Indian standards. Fe exceeds safe limits for drinking water in the ground and surface water. All the measured anions (chloride, sulphate and nitrate) are significantly higher in the ground and surface water as compared to the rainwater and exceeds the WHO and Indian Standards. Nitrate in drinking water is often reduced to nitrite in the stomach by gastric acids and with subsequent reactions with amines and amides results in the formation of $\mathrm{N}$-nitroso compounds that have been linked to different types of cancer [30]. Nitrate $(12.5 \pm 11.8 \mathrm{ppm})$ in the rainwater meets the Indian, WHO and EU standards, but fails to meet the US EPA standard of
$10 \mathrm{ppm}$. Therefore, rainwater needs a bare minimum treatment with respect to inorganic constituents before use as opposed to groundwater and river water, and this makes the use of rainwater more convincing as a drinking source.

\subsection{Wet deposition flux (WDF) of the trace metals}

The WDF calculated during the current study are shown in Table 5 and compared with the WDF data in different Asian countries from the literature. The atmosphere includes a variety of nutrient ions and trace metals adsorbed onto particulate matter that are scavenged by rain. Some of these ions and metals are plant nutrients (such as nitrate, ammonium, $\mathrm{K}, \mathrm{Ca}, \mathrm{Mg}, \mathrm{Fe}$ ) and some of them are toxic such as $\mathrm{Cr}, \mathrm{Cd}, \mathrm{Pb}$, which affect the physico-chemical properties of the soil $[32,48]$.

WDF depend on the solubility of the trace metals and particle size distribution [86]. In Kolkata, the magnitude of the concentrations and fluxes of the different elements were in the order of: $\mathrm{Ca}>\mathrm{Na}>\mathrm{Mg}>\mathrm{Al}>\mathrm{Zn}>\mathrm{Fe}>\mathrm{Mn}>\mathrm{Cu}$ $>\mathrm{Ni}>\mathrm{Pb}>\mathrm{Cr}>\mathrm{V}>\mathrm{Cd}$. Of the primary crustal elements, $\mathrm{Ca}$ exhibited the highest flux of $242 \mathrm{mg} / \mathrm{m}^{2} / \mathrm{yr}$ followed by $\mathrm{Na}, \mathrm{Mg}, \mathrm{Al}$ and $\mathrm{Fe}$. Al, Fe and $\mathrm{Mn}$ represent higher loadings because of their high concentrations in dust derived from crustal materials [23] and $\mathrm{Na}$ has a sea salt origin and comparable with the WDF over IGP. Higher flux values of $\mathrm{Ca}$ and Mg over IGP compared to Kolkata are due to enhanced anthropogenic emissions from power plants, refineries, stone crushing units and numerous medium and small-scale industries over IGP [119]. Among the anthropogenic metals, $\mathrm{Zn}$ had the highest WDF, followed by $\mathrm{Cu}, \mathrm{Ni}, \mathrm{Pb}, \mathrm{Cr}, \mathrm{V}$ and $\mathrm{Cd}$. Despite differences in sampling periods reported in previous studies and the probability of inter-annual variability, WDFs of elements like $\mathrm{Cd}, \mathrm{V}, \mathrm{Cr}$, $\mathrm{Ni}$ and $\mathrm{Cu}$ are in good agreement with those recorded from other sites. The deposition fluxes of $\mathrm{Ni}, \mathrm{Cu}$ and $\mathrm{Zn}$ at Kolkata were more or less similar to Izmir, Turkey, and Singapore both of which are large coastal urban centres where the sources are attributable to local emissions from anthropogenic activities [47, 102]. $\mathrm{V}$ and $\mathrm{Cr}$ fluxes of this study are comparable with different cities of China and Japan but much less than those reported from Turkey and Singapore. Leather tanning, textiles industries and electroplating are significant anthropogenic sources of $\mathrm{Cr}$ in soil, whereas fossil fuel (both coal and oil combustion) and waste incineration releases $\mathrm{Cr}$ in the atmosphere [50]. $\mathrm{V}$ is released from combustion of fossil fuels. Wet deposition of $\mathrm{Cd}$ is comparable with global data. Cd is primarily released from coal combustion, vehicle emissions and industries. $\mathrm{Pb}$ flux is lower than all the compared sites. Post-phasing out of leaded gasoline the largest anthropogenic sources of $\mathrm{Pb}$ is coal combustion followed by nonferrous metal smelters and vehicle exhaust, besides the natural background 


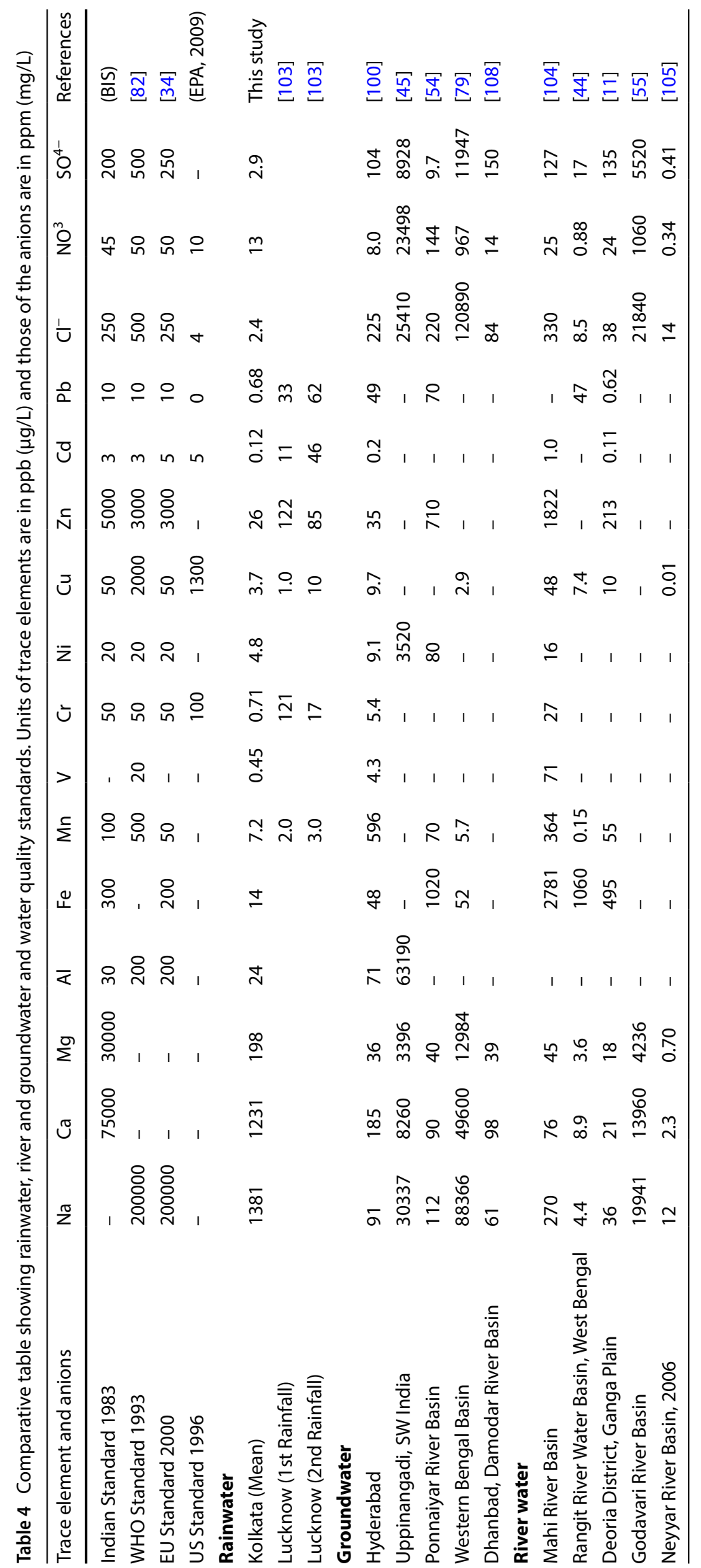




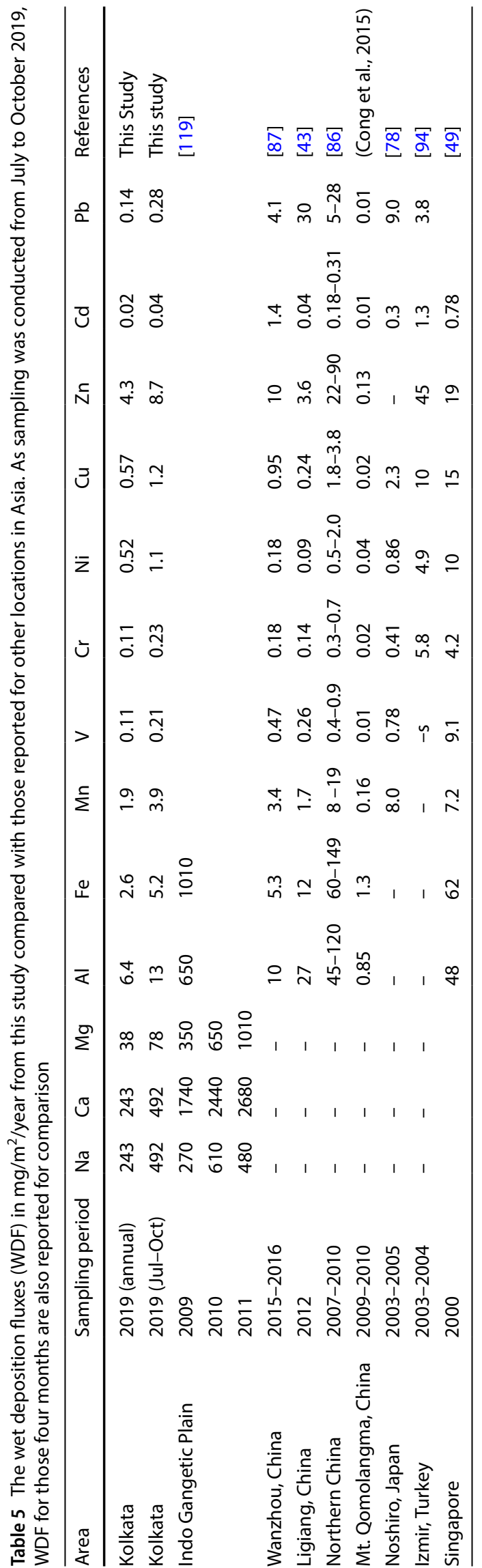

from regional and local soil. Among the compared sites, Mt. Qomolangma in China which is regarded as a remote background site has the least WDF for almost all the trace elements.

\subsection{Limitations of the study}

The current study collected rainwater and aerosol in between rain events during the monsoon season only. In 2019, the total rainfall over Kolkata was $1642 \mathrm{~mm}$ out of which $1127 \mathrm{~mm}$ or $69 \%$ occurred during the sampled monsoon months between July and October. The remaining months of the year except November received less than $100 \mathrm{~mm}$ rainfall. Hence, seasonality of rainwater chemical composition could not be measured in this pilot study. Furthermore ammonia $\left(\mathrm{NH}_{4}^{+}\right)$in rainwater was not measured in this study; thus, neutralization factors could not be analysed. Future study plans to focus on seasonal variation of rainwater metal and major ions concentrations in urban centres and compare it with a less polluted rural site to better understand sources of pollutants in rainwater.

Access to safe drinking water remains an urgent requirement in India, as a large fraction of Indian households ( $30 \%$ of urban and $90 \%$ of rural households) are still dependent on either groundwater or untreated surface water [2]. Though access to drinking water has improved in India over the last decade, the enormous adverse health effects of contaminated water continue. Generally, contaminants in harvested rainwater are derived primarily from the atmosphere; however, rainwater quality deterioration may occur during harvesting, storage and household use [77]. To correctly access the treatment needs of harvested rainwater for drinking purpose, both harvesting conditions and rainwater quality with respect to chemical (organic and inorganic constituents, pesticides, radioactive components, disinfectants), physical and microbiological components should be assessed [1]. Identifying pollutants that are incorporated from the harvesting process and organic and microbiological pollutants quantification of rainwater was not within the scope of this study.

\section{Conclusions}

The present work is a pilot study to assess metal concentrations and major anions in rainwater and quantifying wet deposition flux of the trace metals from a polluted megacity in India. Trace metal chemistry of rainwater is gaining importance as rain water harvesting is one of the strategies that the water sector is increasingly adopting to cope with future climate change. In many areas in China and Middle East, $\mathrm{Pb}$ exceeds WHO guideline limits for safe 
drinking water. In Lucknow, India, several toxic trace metals such as $\mathrm{Pb}, \mathrm{Cr}$ and $\mathrm{Cd}$ exceeds Indian Standards. Kolkata in spite of having poor air quality experienced rainfall with all the trace elements and anions within WHO guideline limits. Hence the rainwater is deemed suitable for drinking purpose with respect to metal content and anions and does not require pre-treatment to remove toxic metals. Comparison of concentration trends and crustal enrichment factor for the trace metals of $\mathrm{PM}_{10}$ and rainwater shows preferential leaching of metals such as $\mathrm{Cu}, \mathrm{Zn}, \mathrm{V}, \mathrm{Cd}$ and $\mathrm{Pb}$. A soluble fraction of the metals enter the ecosystem through wet deposition. The annual WDF for $\mathrm{Pb}$ was much less when compared to other sites around the globe. However, WDF of the remaining metals are comparable to the global data.

Acknowledgement This research was partially supported by UGC Start Up Grant and RUSA 2.0 (Project No: P-11/720/19) awarded to RD. We thank Dr. Tarit Roychowdhury of Jadavpur University, Dr. Xianfeng Wang, Dr. Jeffrey Oalmann, Ms. Lin Ke, Ms. Maria Chong, Ms. Beng Choo and Ms. Pearlyn See Shen Yen at Nanyang Technological University for their help and support in the laboratory.

\section{Compliance with ethical standards}

Conflict of interest On behalf of all authors, the corresponding author states that there is no conflict of interest.

\section{References}

1. Abbasi T, Abbasi SA (2011) Sources of pollution in rooftop rainwater harvesting systems and their control. Crit Rev Environ Sci Technol 41:2097-2167

2. Agapitova, N, Navarrete MC., Barkataky, R. (2017). Waterlife: improving access to safe drinking water in India. World Bank, Washington, DC. ๑ World Bank. https://openknowledge.world bank.org/handle/10986/27664 License: CC BY 3.0 IGO

3. Al-Khashman OA, Jaradat AQ, Salameh E (2013) Five-year monitoring study of chemical characteristics of Wet atmospheric precipitation in the southern region of Jordan. Environ Monit Assess 185:5715-5727

4. Allan, MA. (2004). Manual for the GAW precipitation chemistry programme: guidelines, data quality objectives and standard operating procedures (World Meteorological Organization Geneva (SwitzerlaND))

5. Al-Momani I (2003) Trace elements in atmospheric precipitation at Northern Jordan measured by ICP-MS: acidity and possible sources. Atmos Environ 37:4507-4515

6. Amodio M, Catin S, Dambruoso PR, de Gennaro G, Di Gilio A, Giungato P, Laiola E, Marzocca A, Mazzone A, Sardaro A et al (2014) Atmospheric deposition: sampling procedures, analytical methods, and main recent findings from the scientific literature(Hindawi). Adv Meterol 2014:1-27

7. Anatolaki Ch, Tsitouridou R (2009) Relationship between acidity and ionic composition of wet precipitation: a two years study at an urban site, Thessaloniki, Greece. Atmos Res 92:100-113

8. Barbieri M, Sappa G, Vitale S, Parisse B, Battistel M (2014) Soil control of trace metals concentrations in landfills: a case study of the largest landfill in Europe, Malagrotta, Rome. J Geochem Explor 143:146-154

9. Berg T, Røyset O, Steinnes E (1994) Trace elements in atmospheric precipitation at Norweigan background stations (19891990) measured by ICP-MS. Atmos Environ 28:3519-3536

10. Bhanarkar AD, Rao PS, Gajghate DG, Nema P (2005) Inventory of $\mathrm{SO} 2, \mathrm{PM}$ and toxic metals emissions from industrial sources in Greater Mumbai, India. Atmos Environ 39:3851-3864

11. Bhardwaj V, Singh DS (2011) Surface and groundwater quality characterization of Deoria district, Ganga plain, India. Environ Earth Sci 63:383-395

12. Bhattacharya $S$ (2015) Traditional water harvesting structures and sustainable water management in India: a socio-hydrological review. Int Lett Nat Sci 37:30-38

13. BIS IS: 10500 (2012) Indian Standard: Drinking Water-Specification, first revision. Bureau of Indian Standards, New Delhi, India

14. Budhavant KB, Rao PSP, Safai PD, Ali K (2011) Influence of local sources on rainwater chemistry over Pune region, India. Atmos Res 100:121-131

15. de Burbure $C$, Buchet J-P, Leroyer A, Nisse $C$, Haguenoer J-M, Mutti A, Smerhovský Z, Cikrt M, Trzcinka-Ochocka M, Razniewska G et al (2006) Renal and neurologic effects of cadmium, lead, mercury, and arsenic in children: evidence of early effects and multiple interactions at environmental exposure levels. Environ Health Perspect 114:584-590

16. Cao Y-Z, Wang S, Zhang G, Luo J, Lu S (2009) Chemical characteristics of wet precipitation at an urban site of Guangzhou, South China. Atmos Res 94:462-469

17. Chakraborty B, Gupta A (2014) Rainwater quality analysis in selected areas of eastern and northeastern India. Int J Environ Eng 1:5

18. Chance R, Jickells TD, Baker AR (2015) Atmospheric trace metal concentrations, solubility and deposition fluxes in remote marine air over the south-east Atlantic. Mar Chem 177:45-56

19. Charlson RJ, Rodhe $\mathrm{H}$ (1982) Factors controlling the acidity of natural rainwater. Nature 295:683-685

20. Chaudhary S, Firdaus U, Ali SM, Mahdi AA (2018) Factors associated with elevated blood lead levels in children. Indian Pediatr 55:38-40

21. Cheng Y, Liu Y, Huo M, Sun Q, Wang H, Chen Z, Bai Y (2011) Chemical characteristics of precipitation at Nanping Mangdang Mountain in eastern China during spring. J Environ Sci 23:1350-1358

22. Chifflet $S$, Amouroux D, Bérail S, Barre J, Van TC, Baltrons O, Brune J, Dufour A, Guinot B, Mari X (2018) Origins and discrimination between local and regional atmospheric pollution in Haiphong (Vietnam), based on metal(loid) concentrations and lead isotopic ratios in PM10. Environ Sci Pollut Res 25:26653-26668

23. Cong Z, Kang S, Zhang Y, Li X (2010) Atmospheric wet deposition of trace elements to central Tibetan Plateau. Appl Geochem 25:1415-1421

24. Das N, Das R, Chaudhury GR, Das SN (2010) Chemical composition of precipitation at background level. Atmos Res 95:108-113

25. Das R, Khezri B, Srivastava B, Datta S, Sikdar PK, Webster RD, Wang X (2015) Trace element composition of PM2.5 and PM10 from Kolkata - a heavily polluted Indian metropolis. Atmos Pollut Res 6:742-750

26. Das R, Mohtar BM, TRakshitShome ADDX, Wang (2018) Sources of atmospheric lead $(\mathrm{Pb})$ in and around an Indian megacity. Atmos Environ 193:57-65

27. Das R, Wang X, Itoh M, Shiodera S, Kuwata M (2019) Estimation of metal emissions from tropical peatland burning in Indonesia by controlled laboratory experiments. J Geophy Res: Atmos 124:6583-6599 
28. Deboudt K, Flament P, Bertho M-L (2004) Cd, Cu, Pb and Zn Concentrations in atmospheric wet deposition at a coastal station in Western Europe. Water Air Soil Pollut 151:335-359

29. Deguillaume L, Leriche M, Desboeufs K, Mailhot G, George C, Chaumerliac N (2005) Transition metals in atmospheric liquid phases: sources, reactivity, and sensitive parameters. Chem Rev 105:3388-3431

30. Dkhar EN, Dkhar PS, Anal JMH (2014) Trace elements analysis in drinking water of Meghalaya by using graphite furnace-atomic absorption spectroscopy and in relation to environmental and health issues (Hindawi). J chem 2014:1-7

31. Domínguez I, Ward S, Mendoza JG, Rincón Cl, Oviedo-Ocaña ER (2017) End-user cost-benefit prioritization for selecting rainwater harvesting and greywater reuse in social housing. Water 9:516

32. Duan L, Song J, Xu Y, Li X, Zhang Y (2010) The distribution, enrichment and source of potential harmful elements in surface sediments of Bohai Bay, North China. J Hazard Mat 183:155-164

33. EPA U (2009). National primary drinking water regulations. Arsenic and Clarifications To

34. Flanagan PJ (1988). Parameters of water quality: interpretation and standards (Environmental Research Unit)

35. de Foy B, Krotkov NA, Be N, Herndon SC, Huey LG, Martinez AP, Ruiz-Suarez LG., Wood EC, Zavala M, Molina LT (2009). Hit from both sides: tracking industrial and volcanic plumes in Mexico City with surface measurements and $\mathrm{OMI} \mathrm{SO} 2$ retrievals during the MILAGRO field campaign. Copernicus

36. Gheorghe IF, Ion B (2011) The effects of air pollutants on vegetation and the role of vegetation in reducing atmospheric pollution. The Impact of Air Pollution on Health, Economy, Environment and Agricultural Sources

37. Gillette DA, Stensland GJ, Williams AL, Barnard W, Gatz D, Sinclair PC, Johnson TC (1992) Emissions of alkaline elements calcium, magnesium, potassium, and sodium from open sources in the contiguous United States. Global Biogeochem Cycles 6:437-457

38. Glendenning CJ, van Ogtrop FF, Mishra AK, Vervoort RW (2012) Balancing watershed and local scale impacts of rain water harvesting in India-A review. Agric Water Manag 107:1-13

39. Gobre T, Salve PR, Krupadam RJ, Bansiwal A, Shastry S, Wate SR (2010) Chemical composition of precipitation in the coastal environment of India. Bull Environ Contam Toxicol 85:48-53

40. Gowd SS, Reddy MR, Govil PK (2010) Assessment of heavy metal contamination in soils at Jajmau (Kanpur) and Unnao industrial areas of the Ganga Plain, Uttar Pradesh, India. J Hazard Mater 174:113-121

41. Grantz DA, Garner JHB, Johnson DW (2003) Ecological effects of particulate matter. Environ Int 29:213-239

42. Guagliardi I, Buttafuoco G, Cicchella D, De Rosa R (2013) A multivariate approach for anomaly separation of potentially toxic trace elements in urban and peri-urban soils: an application in a southern Italy area. J Soils Sediments 13:117-128

43. Guo J, Kang S, Huang J, Zhang Q, Tripathee L, Sillanpää M (2015) Seasonal variations of trace elements in precipitation at the largest city in Tibet, Lhasa. Atmos Res 153:87-97

44. Gupta S, Nayek S, Chakraborty D (2016) Hydrochemical evaluation of Rangit river, Sikkim, India: using water quality Index and multivariate statistics. Environ Earth Sci 75:567

45. Gurumurthy GP, Balakrishna K, Tripti M, Riotte J, Audry S, Braun J-J, Lambs L, Udaya Shankar HN (2015) Sources of major ions and processes affecting the geochemical and isotopic signatures of subsurface waters along a tropical river, Southwestern India. Environ Earth Sci 73:333-346

46. Haldar D, Halder S, Das (Saha), P., and Halder, G. (2016) Assessment of water quality of Damodar River in South Bengal region of India by Canadian Council of Ministers of Environment (CCME) Water Quality Index: a case study. Desalination Water Treat 57:3489-3502

47. Hjortenkrans DST, Bergbäck BG, Häggerud AV (2007) Metal emissions from brake linings and tires: case studies of Stockholm, Sweden 1995/1998 and 2005. Environ Sci Technol 41:5224-5230

48. Hovmand MF, Kemp K, Kystol J, Johnsen I, Riis-Nielsen T, Pacyna JM (2008) Atmospheric heavy metal deposition accumulated in rural forest soils of southern Scandinavia. Environ Pollut 155:537-541

49. Hu G-P, Balasubramanian R (2003) Wet deposition of trace metals in Singapore. Water Air Soil Pollut 144:285-300

50. Hu Y, Cheng H (2013) Application of stochastic models in identification and apportionment of heavy metal pollution sources in the surface soils of a large-scale region. Environ Sci Technol 47:3752-3760

51. Huston R, Chan YC, Gardner T, Shaw G, Chapman H (2009) Characterisation of atmospheric deposition as a source of contaminants in urban rainwater tanks. Water Res 43:1630-1640

52. Hutton M (1983) Sources of cadmium in the environment. Ecotoxicol Environ Saf 7:9-24

53. Jawad Al Obaidy AHM, Joshi H (2006) Chemical composition of rainwater in a tropical urban area of northern India. Atmos Environ 40:6886-6891

54. Jeevanandam M, Kannan R, Srinivasulu S, Rammohan V (2006) Hydrogeochemistry and groundwater quality assessment of lower part of the Ponnaiyar River Basin, Cuddalore district, South India. Environ Monit Assess 132:263-274

55. Jha PK, Tiwari J, Singh UK, Kumar M, Subramanian V (2009) Chemical weathering and associated $\mathrm{CO} 2$ consumption in the Godavari river basin, India. Chem Geol 264:364-374

56. Kanellopoulou EA (2001) Determination of heavy metals in wet deposition of Athens. Global Nest J 3:45-50

57. Karar K, Gupta AK (2007) Source apportionment of PM10 at residential and industrial sites of an urban region of Kolkata, India. Atmos Res 84:30-41

58. Kasprzak KS, Sunderman FW, Salnikow K (2003) Nickel carcinogenesis. Mutat Res/Fundam Mol Mech Mutagen 533:67-97

59. Kayee J, Sompongchaiyakul P, Sanwlani N, Bureekul S, Wang X, Das R (2020) Metal concentrations and source apportionment of pm2.5 in Chiang Rai and Bangkok, Thailand during a biomass burning season. ACS Earth Space Chem 4:1213-1226

60. Keresztesi Á, Nita I-A, Boga R, Birsan M-V, Bodor Z, Szép R (2020) Spatial and long-term analysis of rainwater chemistry over the conterminous United States. Environ Res 188:109872

61. Khare P, Goel A, Patel D, Behari J (2004) Chemical characterization of rainwater at a developing urban habitat of Northern India. Atmos Res 69:135-145

62. Kibria G, Hossain MM, Mallick D, Lau TC, Wu R (2016) Monitoring of metal pollution in waterways across Bangladesh and ecological and public health implications of pollution. Chemosphere 165:1-9

63. Kim ND, Fergusson JE (1994) The concentrations, distribution and sources of cadmium, copper, lead and zinc in the atmosphere of an urban environment. Sci Total Environ 144:179-189

64. Kim G, Scudlark JR, Church TM (2000) Atmospheric wet deposition of trace elements to Chesapeake and Delaware bays. Atmos Environ 34:3437-3444

65. Kitayama K, Murao N, Hara H (2010) PMF analysis of impacts of SO2 from Miyakejima and Asian continent on precipitation sulfate in Japan. Atmos Environ 44:95-105

66. Kulshrestha UC, Kulshrestha MJ, Sekar R, Sastry GSR, Vairamani $M$ (2003) Chemical characteristics of rainwater at an urban site of south-central India. Atmos Environ 37:3019-3026 
67. Kumar D, Katoch SS (2014) Harnessing 'water tower' into'power tower': a small hydropower development study from an Indian prefecture in western Himalayas. Renew Sustain Energy Rev 39:87-101

68. Kumar B, Rai SP, Kumar US, Verma SK, Garg P, Kumar SVV, Jaiswal R, Purendra BK, Kumar SR, Pande NG (2010) Isotopic characteristics of Indian precipitation. Water Resour Res. https://doi. org/10.1029/2009WR008532

69. Landing WM, Caffrey JM, Nolek SD, Gosnell K (2009) Atmospheric wet deposition of mercury and other trace elements in Pensacola. Florida Atmos Chem Phys Discuss 9:27649-27674

70. Lee J-M, Boyle EA, Suci Nurhati I, Pfeiffer M, Meltzner AJ, Suwargadi $B$ (2014) Coral-based history of lead and lead isotopes of the surface Indian Ocean since the mid-20th century. Earth Planet Sci Lett 398:37-47

71. Li X, Lee S, Wong S, Shi W, Thornton I (2004) The study of metal contamination in urban soils of Hong Kong using a GIS-based approach. Environ Pollut 129:113-124

72. Menz FC, Seip HM (2004) Acid rain in Europe and the United States: an update. Environ Sci Policy 7:253-265

73. Meyer C, Diaz-de-Quijano M, Monna F, Franchi M, Toussaint M-L, Gilbert D, Bernard N (2015) Characterisation and distribution of deposited trace elements transported over long and intermediate distances in north-eastern France using Sphagnum peatlands as a sentinel ecosystem. Atmos Environ 101:286-293

74. Migliavacca D, Teixeira EC, Wiegand F, Machado ACM, Sanchez J (2005) Atmospheric precipitation and chemical composition of an urban site, Guaíba hydrographic basin, Brazil. Atmos Environ 39:1829-1844

75. Mijic Z, Stojic A, Perisic M, Rajsic S, Tasic M (2012) Receptor modeling studies for the characterization of $\mathrm{PM} 10$ pollution sources in Belgrade. $\mathrm{Cl}$ and CEQ 18:623-634

76. Mirzaei S, Hashemi H, Hoseini M (2018) Concentration and potential source identification of trace elements in wet atmospheric precipitation of Shiraz. Iran J Environ Health Sci Eng 16:229-237

77. Morrow AC, Dunstan RH, Coombes PJ (2010) Elemental composition at different points of the rainwater harvesting system. Sci Total Environ 408:4542-4548

78. Muezzinoglu A, Cizmecioglu SC (2006) Deposition of heavy metals in a Mediterranean climate area. Atmos Res 81:1-16

79. Mukherjee $A$, Bhattacharya $P$, Shi F, Fryar AE, Mukherjee AB, Xie ZM, Jacks G, Bundschuh J (2009) Chemical evolution in the high arsenic groundwater of the Huhhot basin (Inner Mongolia, PR China) and its difference from the western Bengal basin (India). Appl Geochem 24:1835-1851

80. Niu H, He Y, Lu XX, Shen J, Du J, Zhang T, Pu T, Xin H, Chang L (2014) Chemical composition of rainwater in the Yulong Snow Mountain region, Southwestern China. Atmos Res 144:195-206

81. Norman M, Das SN, Pillai AG, Granat L, Rodhe H (2001) Influence of air mass trajectories on the chemical composition of precipitation in India. Atmos Environ 35:4223-4235

82. Organization WH (2017) Guidelines for drinking-water quality: first addendum to the, 4th edn. First Addendum to the Fourth Edition, Guidelines for Drinking-Water Quality

83. Ozkurt N, Sari D, Akalin N, Hilmioglu B (2013) Evaluation of the impact of $\mathrm{SO} 2$ and $\mathrm{NO} 2$ emissions on the ambient air-quality in the Çan-Bayramiç region of northwest Turkey during 20072008. Sci Total Environ 456-457:254-266

84. Pacyna JM, Pacyna EG (2001) An assessment of global and regional emissions of trace metals to the atmosphere from anthropogenic sources worldwide. Environ Rev 9:269-298

85. Pacyna JM, Pacyna EG, Aas W (2009) Changes of emissions and atmospheric deposition of mercury, lead, and cadmium. Atmos Environ 43:117-127
86. Pan YP, Wang YS (2015) Atmospheric wet and dry deposition of trace elements at 10 sites in Northern China. Atmos Chem Phys 15:951-972

87. Peng Y-L, Wang Y-M, Qin C-Q, Wang D-Y (2014) Concentrations and deposition fluxes of heavy metals in precipitation in core urban areas, Chongqing. Huan Jing Ke Xue 35:2490-2496

88. Prathibha P, Kothai P, Saradhi IV, Pandit GG, Puranik VD (2010) Chemical characterization of precipitation at a coastal site in Trombay, Mumbai, India. Environ Monit Assess 168:45-53

89. Rajeev P, Rajput P, Gupta T (2016) Chemical characteristics of aerosol and rain water during an El Niño and PDO influenced Indian summer monsoon. Atmos Environ 145:192-200

90. Rao PSP, Tiwari S, Matwale JL, Pervez S, Tunved P, Safai PD, Srivastava AK, Bisht DS, Singh S, Hopke PK (2016) Sources of chemical species in rainwater during monsoon and non-monsoonal periods over two mega cities in India and dominant source region of secondary aerosols. Atmos Environ 146:90-99

91. Ravichandran C, Padmanabhamurty B (1994) Acid precipitation in Delhi, India. Atmos Environ 28:2291-2297

92. Rivera-Rivera DM, Escobedo-Urías DC, Jonathan MP, Sujitha SB, Chidambaram S (2020) Evidence of natural and anthropogenic impacts on rainwater trace metal geochemistry in central Mexico: a statistical approach. Water 12:192

93. Rudnick RL, Gao S (2003) Composition of the continental crust. Treat Geochem 3:659

94. Sakata M, Asakura K (2009) Factors contributing to seasonal variations in wet deposition fluxes of trace elements at sites along Japan Sea coast. Atmos Environ 43:3867-3875

95. Sakata M, Marumoto K, Narukawa M, Asakura K (2006) Regional variations in wet and dry deposition fluxes of trace elements in Japan. Atmos Environ 40:521-531

96. Sakihama H, Ishiki M, Tokuyama A (2008) Chemical characteristics of precipitation in Okinawa Island, Japan. Atmos Environ 42:2320-2335

97. Salve PR, Maurya A, Wate SR, Devotta S (2008) Chemical composition of major ions in rainwater. Bull Environ Contam Toxicol $80: 242-246$

98. Samara C, Tsitouridou R (2000) Fine and Coarse ionic aerosol components in relation to wet and dry deposition. Water Air Soil Pollut 120:71-88

99. Santos PSM, Otero M, Santos EBH, Duarte AC (2011) Chemical composition of rainwater at a coastal town on the southwest of Europe: What changes in 20years? Sci Total Environ 409:3548-3553

100. Satyanarayanan M, Balaram V, Al Hussin MS, Al Jemaili MAR, Rao TG, Mathur R, Dasaram B, Ramesh SL (2007) Assessment of groundwater quality in a structurally deformed granitic terrain in Hyderabad, India. Environ Monit Assess 131:117-127

101. Seinfeld, J.H., and Pandis, S.N. (2016). Atmospheric chemistry and physics: from air pollution to climate change (John Wiley and Sons)

102. Shao X, Cheng H, Li Q, Lin C (2013) Anthropogenic atmospheric emissions of cadmium in China. Atmos Environ 79:155-160

103. Sharma P, Rai V (2018) Assessment of rain water chemistry in the Lucknow metropolitan city. Appl Water Sci 8:67

104. Sharma A, Singh AK, Kumar K (2012) Environmental geochemistry and quality assessment of surface and subsurface water of Mahi River basin, western India. Environ Earth Sci 65:1231-1250

105. Sheeja RV, Sheela AM, Jaya S, Joseph S (2020) Assessment of water quality of a tropical river with special reference to ions. Current J App Sci Technol 97-116. https://doi.org/10.9734/cjast /2020/v39i1830779

106. Shukla SP, Mukesh S (2010) Neutralization of rainwater acidity at Kanpur, India. Tellus B: Chem Phys Meteorol 62:172-180 
107. Shukla SP, Sharma M (2010) Neutralization of rainwater acidity at Kanpur, India. Tellus B 62:172-180

108. Singh AK, Mondal GC, Kumar S, Singh TB, Tewary BK, Sinha A (2008) Major ion chemistry, weathering processes and water quality assessment in upper catchment of Damodar River basin. Environmental Geology, India. https://doi.org/10.1007/ s00254-007-0860-1

109. Singh AK, Mondal GC, Kumar S, Singh KK, Kamal KP, Sinha A (2007) Precipitation chemistry and occurrence of acid rain over Dhanbad, Coal City of India. Environ Monit Assess 125:99-110

110. Singh KP, Singh VK, Malik A, Sharma N, Murthy RC, Kumar R (2007) Hydrochemistry of wet atmospheric precipitation over an urban area in northern Indo-Gangetic plains. Environ Monit Assess 131:237-254

111. Singh N, Murari V, Kumar M, Barman SC, Banerjee T (2017) Fine particulates over South Asia: review and meta-analysis of PM2.5 source apportionment through receptor model. Environ Pollut 223:121-136

112. Smith SJ, van Aardenne J, Klimont Z, Andres RJ, Volke A, Delgado Arias $S$ (2011) Anthropogenic sulfur dioxide emissions: 1850-2005. Atmos Chem Phys 11:1101-1116

113. Song F, Gao Y (2009) Chemical characteristics of precipitation at metropolitan Newark in the US East Coast. Atmos Environ 43:4903-4913

114. Sumari SM, Muhamad-Darus F, Kantasamy N, Urban Sinyaw S, ak, (2010) Rainwater characterization at global atmospheric watch in Danum valley, Sabah. 2010 International Conference on Science and Social Research (CSSR 2010), (Kuala Lumpur. IEEE), Malaysia, pp 479-484

115. Szép R, Bodor Z, Miklóssy I, Niță I-A, Oprea OA, Keresztesi Á (2019) Influence of peat fires on the rainwater chemistry in intra-mountain basins with specific atmospheric circulations (Eastern Carpathians, Romania). Sci Total Environ 647:275-289

116. Tang $X$ (2007) The studies and analyses of precipitation acidity and chemical composition in industriale state locates in north bank of the Yangtze River. Nanjing. Nanjing University of Information Science \& Technology, Nanjing

117. Teixeira EC, Migliavacca D, Pereira Filho S, Machado ACM, Dallarosa JB (2008) Study of wet precipitation and its chemical composition in South of Brazil. An Acad Bras Ciênc 80:381-395

118. Tian HZ, Lu L, Cheng K, Hao JM, Zhao D, Wang Y, Jia WX, Qiu PP (2012) Anthropogenic atmospheric nickel emissions and its distribution characteristics in China. Sci Total Environ 417-418:148-157

119. Tiwari S, Hopke PK, Thimmaiah D, Dumka UC, Srivastava AK, Bisht DS, Rao PSP, Chate DM, Srivastava MK, Tripathi SN (2016) Nature and sources of ionic species in precipitation across the Indo-Gangetic Plains. India Aerosol Air Qual Res 16:943-957
120. Topçu S, Incecik S, Atimtay AT (2002) Chemical composition of rainwater at EMEP station in Ankara, Turkey. Atmos Res 65:77-92

121. Vahlsing C, Smith KR (2012) Global review of national ambient air quality standards for PM10 and SO2 (24 h). Air Qual Atmos Health 5:393-399

122. Varol M, Şen B (2012) Assessment of nutrient and heavy metal contamination in surface water and sediments of the upper Tigris River, Turkey. CATENA 92:1-10

123. Velis M, Conti Kl, Biermann F (2017) Groundwater and human development: synergies and trade-offs within the context of the sustainable development goals. Sustain Sci 12:1007-1017

124. Vlastos D, Antonopoulou M, Lavranou A, Efthimiou I, Dailianis S, Hela D, Lambropoulou D, Paschalidou AK, Kassomenos P (2019) Assessment of the toxic potential of rainwater precipitation: first evidence from a case study in three Greek cities. Sci Total Environ 648:1323-1332

125. Wetang'ula GN, Wamalwa HM. Trace elements in rainfall collected around Menengai Area Kenya. In: Proceedings World Geothermal Congress, pp 13-25

126. Wu Y-S, Fang G-C, Lee W-J, Lee J-F, Chang C-C, Lee C-Z (2007) A review of atmospheric fine particulate matter and its associated trace metal pollutants in Asian countries during the period 1995-2005. J Hazard Mat 143:511-515

127. Xing J, Song J, Yuan H, Wang Q, Li X, Li N, Duan L, Qu B (2017) Atmospheric wet deposition of dissolved trace elements to Jiaozhou Bay, North China: fluxes, sources and potential effects on aquatic environments. Chemosphere 174:428-436

128. Xu Z, Li Y, Tang Y, Han G (2009) Chemical and strontium isotope characterization of rainwater at an urban site in Loess Plateau, Northwest China. Atmos Res 94:481-490

129. Yang F, Tan J, Shi ZB, Cai Y, He K, Ma Y, Duan F, Okuda T, Tanaka $S$, Chen $G$ (2012) Five-year record of atmospheric precipitation chemistry in urban Beijing, China. Atmos Chem Phys 12:2025-2035

130. Ym L, Yp P, Ys W, Yf W, Xr L (2012) Chemical characteristics and sources of trace metals in precipitation collected from a typical industrial city in Northern China. Huan Jing Ke Xue 33:3712-3717

Publisher's Note Springer Nature remains neutral with regard to jurisdictional claims in published maps and institutional affiliations. 